\title{
PLATO'S IDEAL AND THE PERVERSITY OF POLITICS
}

\author{
Mark G. Yudof*
}

Educational Policy Making and the Courts: AN Empirical Study of Judicial Activism. By Michael $A$. Rebell and Arthur $R$. Block. Chicago: The University of Chicago Press. 1982. Pp. xv, 319. \$23.

\section{It will help us to cherish Plato's ideal, without sharing his hasty conclusion about the perversity of those who do not listen to reason. ${ }^{1}$}

Educational Policy Making and the Courts, as its subtitle suggests, is much less concerned with demarcating the boundaries of judicial intervention in public school controversies than it is with exploring, from an empirical perspective, the competing assertions frequently made by proponents and opponents of judicial activism. The education sphere, in the light of the controversial nature of many judicial decisions involving teacher seniority, school finance, student rights, bilingual education, and the like, provides a convenient and appropriate context in which to test various hypotheses on the capabilities of courts and the legitimacy of their decisions (p. xi). ${ }^{2}$ The authors are extremely ambitious. They seek to close the "gap between theoretical debates about judicial activism and empirical research into actual trial court behavior" (p. xii). If the book does not entirely succeed, and it does not, this does not detract from the pathbreaking nature of the enterprise. Others may build on their research, refining the methodology and more carefully delineating the limits of empirical research with respect to the vexing normative issues of judicial activism.

I.

Rebell and Block were influenced by the views of Abram Chayes, who warmly endorses the book on the dust cover, and in many respects the book attempts to test empirically assertions made by Chayes in his perceptive 1976 article in the Harvard Law Review. ${ }^{3}$ Chayes suggested that the courts have entered a new era of public law litigation and that this type of litiga-

* Visiting Professor of Law, University of Michigan Law School; Marrs McLean Professor of Law, University of Texas School of Law. - Ed.

1. W. Lippmann, Public Opinion 261 (1965).

2. See, e.g., R. Elmore \& M. McLaughlin, Reform and Retrenchment: The Polltics of California School Finance Reform (1982); D. Horowitz, The Courts and Social Policy (1977); R. Lehne, The Quest For Justice (1978); Limits of Justice (H. Kalodner \& J. Fishman eds. 1978).

3. Chayes, The Role of the Judge in Public Law Litigation, 89 HARv. L. REv. 1281 (1976). See also Chayes, Foreword: Public Law Litigation and the Burger Court, 96 Harv. L. REv. 4 (1982). 
tion, involving the operation of public policy and complex institutions, contrasts markedly with traditional litigation involving only disputes between private individuals about private rights (p. 4). Traditional litigation is "bipolar" (involving two opposing interests) and "retrospective" (liability turns on events that have already occurred). The remedies flow naturally from the rights, with the impact of a remedy largely being limited to the immediate parties. Notwithstanding Chief Justice Marshall's dictum on the separation of rights and remedies in Marbury v. Madison, ${ }^{4}$ traditional litigation treats them as highly interdependent. Corbin was more accurate when he said that "[i]n the whole field of law there is no right without a remedy. . . . [T] [The only useful test as to the existence of a right is that some legal remedy is provided."s

The "new model" litigation departs significantly from these generalizations. The litigation is "multipolar," involving many parties and interests, and the aim is frequently to correct systemic wrongs in complex institutional settings, ${ }^{6}$ e.g., mental hospitals, public schools, and police departments. The focus may be on group rights (blacks, prisoners, students) more than on individual hurts. ${ }^{7}$ Given the nature of the wrongs, predictions as to future occurrences are as important as past events, and the remedies are often broad and require significant changes over time in institutional regularities. Remedies do not flow inexorably from the wrongs, ${ }^{8}$ and the impact of a court order usually will be felt more widely than in traditional law suits. In order to deal adequately with the factual complexities and to ease the process of implementation, ${ }^{9}$ decrees are often negotiated by the parties. The judge's role then becomes more one of orchestrating the proceedings, prodding the parties to agree, and building support among the relevant interest groups, than one of a neutral umpire mandating a particular remedy. ${ }^{10}$

Professor Chayes' article is largely descriptive, and its primary contribution lay in articulating, organizing, and synthesizing changes in the judicial process that lawyers, judges, and scholars only inchoately understood. While the new model does not describe all modern litigations, it focuses attention on the differences in decisional processes between traditional pri-

4. 5 U.S. (1 Cranch) 137, 162-63 (1803).

5. 5 A. Corbin, Corbin on Contracts 2 (1964).

6. See generally Symposium: Legal Remedies in a Society of Large-Scale Organizations, 1981 WIS. L. REv. 861.

7. See generally Fiss, Groups and the Equal Protection Clause, 5 PhiL. \& Pub. AFr. 107 (1976); Van Dyke, Justice as Fairness: For Groups?, 69 AM. POL. SCI. REv. 607 (1975).

8. See, e.g., Rhode, Class Conficts in Class Actions, 34 Stan. L. Rev. 1183, 1195-200 (1982); Yudof, School Desegregation: Legal Realism, Reasoned Elaboration, and Social Science Research in the Supreme Court, 42 LAW \& CONTEMP. ProBS., Autumn 1978, at 57.

9. See, e.g., Kirp, Legalism and Politics in School Desegregation, 1981 WIs. L. Rev. 924 (discussing the political aspects of implementing school desegregation); Yudof, Implementation Theories and Desegregation Realities, 32 ALA. L. REv. 441 (1980-1981). See generally M. MCLaughlin, Evaluation and Reform: The Elementary and Secondary Education ACT OF 1965, TITLE I (1975); Berman, The Study of Macro- and Micro-Implementation, 26 PuB. Poly. 157 (1978); Elmore, Backward Mapping: Implementation Research and Policy Decisions, 94 PoL. SCI. Q. 601 (1979); Elmore, Organizational Models of Social Program Implementation, 26 PUB. POLY. 185 (1978).

10. See Diver, The Judge as Political Power Broker, 65 VA. L. Rev. 43 (1979). 
vate law claims (e.g., contracts, torts, and property) and more controversial constitutional and statutory litigations in such diverse areas as reapportionment, school desegregation, and employment discrimination. The new model clarifies the often heated debates over standing, class actions, ripeness, and mootness by revealing that the antagonists often hold widely disparate views as to the nature of the judicial process. ${ }^{11}$ But equally as important, Chayes' analysis poses problems for those defending and advocating an expansive role for the judiciary. If courts are to engage in broad factfinding to decide multipolar disputes, and to participate in the fashioning of broad remedies oriented to the future, are they not acting as legislative bodies? How competent are courts to engage in such tasks? What do courts know about interpreting social science evidence? ${ }^{12}$ Do the parties before courts represent the full range of interests in a policy area? Is not the adversarial process too piecemeal for the articulation of broad policy? How can courts monitor and enforce decrees requiring widespread cooperation and institutional action? In short, do courts have the institutional capability to perform the tasks assigned to them or assumed by them under the public interest litigation model? ${ }^{13}$

Capability, of course, is not unrelated to legitimacy of authority. Deference is frequently accorded those who exercise authority wisely. For example, patients may allow physicians to exercise authority over their care because they think that physicians know best, that they make good decisions, that they provide needed treatment in a highly skilled manner. ${ }^{14}$ Similarly, if courts are discharging their new responsibilities well, this may be a reason to continue to assign those responsibilities to courts. Chayes said as much in his public law litigation article, cryptically defending judicial activism on instrumental grounds. ${ }^{15}$

But the ache of judicial review in a democracy does not go away so easily. Tyrants may also make sound decisions; the trains may run on time; the economy and standard of living may improve. But the exercise of authority, however capably or wisely, may be illegitimate. As Robert Dahl and Charles Lindblom have stated, democracy requires that citizens have the "last say," that they have the real ability to select leaders and influence policy decisions. The "First Problem of Politics . . . is the antique and yet ever recurring problem of how citizens can keep their rulers from becoming tyrants."16 While it may be fatuous to believe that a majority of citizens actually approves of every decision made by public officials, the consent of the governed requires, at a minimum, a process of consultation between leaders and the citizenry, a process that legitimates the exercise of

11. See generally Chayes, Foreword: Public Law Litigation and the Burger Court, 96 HARv. L. REV. 4 (1982); Rhode, supra note 8.

12. See, e.g., Wolf, Northern School Desegregation and Residential Choice, 1977 SuP. CT. REV. 63.

13. See references in note 2 supra. See also Diver, supra note 10; Glazer, Should Judges Administer Social Services?, 50 PUB. INTEREST 64 (1978); Kirp, supra note 9; Note, Implementation Problems in Institutional Reform Litigation, 91 HARV. L. REv. 428 (1977).

14. See C. Lindblom, Politics and Markets 18 (1977).

15. See Chayes, supro note 3, at 1313-16.

16. R. Dahl \& C. Lindblom, Politics, Economics and Welfare 273, 276 (1976). 
authority. 17

In riveting our attention to the new breed of public interest litigation, Professor Chayes takes us beyond the capability question, and reopens the traditional debate over the legitimacy of courts entertaining such litigations. As law suits begin to resemble, less and less, traditional bipolar litigations, one significant justification for judicial review begins to fade. Chief Justice Marshall argued 180 years ago that "[i]t is emphatically the province and duty of the judicial department to say what the law is. Those who apply the rule to particular cases, must of necessity expound and interpret that rule." 18 In part, he defended judicial review on the ground that the judiciary must interpret and apply the Constitution and laws, as duly enacted, if it were charged with the responsibility of deciding concrete cases. Many have disagreed with Marshall, particularly with regard to the finality of judicial review. ${ }^{19}$ But what if, as Chayes' analysis suggests, courts were deciding matters of broad public policy in the absence of a "case" or "law" in the traditional sense? Is the exercise of judicial authority legitimate under such circumstances? ${ }^{20}$

In responding to such quandaries, Rebell and Block move beyond the utilitarian defense of Chayes, perhaps sensing that utility alone is not enough $^{21}$ and that, in any event, there are conflicting views as to the efficacy of the courts' work in public interest cases. They rely upon the theories of Herbert Wechsler ${ }^{22}$ and Ronald Dworkin" ${ }^{23}$ for the proposition that "[t]o the extent that courts decide issues in terms of 'principles,' they are acting within the proper sphere of judicial decision making; to the extent that they decide issues in terms of 'policies,' they are, according to the critics, intruding into the legislative or executive domain" (p. 23). Strangely enough, there is not much elaboration by the authors as to how principled judicial decisionmaking enhances the legitimacy of the exercise of judicial authority. They largely limit themselves to quoting from Dworkin:

[T] he line between "principle" and "policy" is difficult to establish. . . . Nevertheless, we agree with Dworkin that "the direction to these judges to decide cases on grounds of principle cannot have the same effect that the direction to decide on grounds of policy would have." [P. 23.]

\section{As Charles Frankel put it,}

"Government by consent" cannot be interpreted to mean that those who are governed necessarily agree with what their rulers decide to do. Nor can it mean that "the majority" agrees. For in a democracy the minority, too, is presumably governed by its consent. But to speak of majorities and minorities and the inevitability of disagreements is to suggest what "government by consent" expresses. It expresses the hope for a society in which ordinary people can influence the actions their leaders take ... . [T] obey only after having been actively consulted by those who issue the orders.

C. Frankel, The Democratic Prospect 34 (1962).

18. Marbury v. Madison, 5 U.S. (1 Cranch) 137, 177 (1803). See also The Federalist, No. 78, at 525 (A. Hamilton) (J. Cooke ed. 196I).

19. See, e.g., L. HaNd, The Bill of Rights 9-10 (1958).

20. See Hart, American Jurisprudence Through English Eyes: The Nightmare and the Noble Dream, 11 GA. L. REv. 969 (1977).

21. See generally R. Dworkin, TAKINg Rights Seriously (1977). (1959).

22. See Wechsler, Toward Neutral Principles of Constitutional Law, 73 HARv. L. Rev. 1
23. See R. DWORKIN, supra note 21 . 
The same assertion is made at a number of other points in the book (e.g., pp. xi-xii, 7, 201).

The failure to elaborate on principled decisionmaking is unfortunate. This is evident in the commingling of the theories of Wechsler and Dworkin. Presumably, the requirements of neutral principles and reasoned elaboration of those principles in judicial opinions reflect the notion that judicial power should not be exercised in the same manner as legislative power. The corollary assumption is that the expertise of courts lies in articulating and applying neutral principles, that they have been delegated responsibility to resolve controversies by reasoning by example or analogy in accordance with "a coherent body of principled rules."24 And, more than that, the principles and applications should be embedded in a "comprehensive system," a commitment that Lon Fuller argued leads to reliance on "legal fictions." 25

The mode of decisionmaking required of courts is, in some loose sense, a substitute for the substantive and procedural rules adopted by elective bodies to control discretion in government bureaucracies. ${ }^{26}$ But neutrality of principle cannot suffice. As the late Alexander Bickel noted, it leaves the "hardest questions" unanswered: "Which values, among adequately neutral and general ones, qualify as sufficiently important or fundamental or whathaveyou to be vindicated by the Court against other values affirmed by legislative acts?"27 The contribution of Dworkin to the debate, in the authors' words, is his argument that "legal rights may be based not only on a discrete set of applicable precedents and statutes, but also on justifying principles derived from institutional structures and morality, and political theories integrating the two" (p. 9).

A legitimate principle needs to be more than general and neutral; it needs to be derived from a legitimate source. Otherwise, the principle itself is illegitimate. Thus, the legitimacy of judicial activism in constitutional litigation cannot be determined, absent agreement on a theory of constitutional interpretation that identifies legitimate sources for principles. But the authors do not propound such a theory. They do not respond to Dworkin's many critics. ${ }^{28}$ They do not pick a point on the continuum from Thomas Grey's unwritten constitution ${ }^{29}$ to Raoul Berger's search for original intent in text and history. ${ }^{30}$ They appear agnostic about the nature of the principles they examine.

By virtue of its conceptualization, the study then is largely limited to comparing the decisionmaking approaches of legislative and judicial bodies, and, as the authors admit, the results are inconclusive as to the legitimacy of judicial activism (p. 25). Even assuming that courts and litigants frame policy arguments in terms of principle, a natural tendency if they are

24. A. Bickel, The Least Dangerous Branch 25 (1962).

25. L. Fuller, Legal Fictions 49-53 (1967).

26. See generally K. Davis, Discretionary Justice (1969); T. LOWI, THE END OF Liberalism (2d ed. 1979); P. Selznick, LaW, Society, ANd Industrial Justice (1969).

27. A. BICKEL, supra note 24 , at 55.

28. See, e.g., Greenawalt, Policy, Rights, and Judicial Decision, 11 GA. L. REv. 991 (1977).

29. See Grey, Do We Have an Unwritten Constitution?, 27 Stan. L. REv. 703 (1975).

30. See R. Berger, GovernMENT BY JUdiCIARY (1977). 
to avoid charges of usurpation of authority, and assuming further that policies and principles can be distinguished in hard cases (a point the authors found sticky), the inferences to be drawn are quite limited. Educational Policy Making and the Courts tells us more about the differences in how courts and legislatures approach problems, and how the authors approach courts and legislatures, than it does about the legitimacy of judicial activism.

\section{II}

The major empirical component of Educational Policy Making and the Courts is a study of 65 randomly selected education cases litigated in federal district courts between 1970 and 1977 (p. 21). Individual document files were assembled for each of the "caselets," and researchers reviewed court opinions, key pleadings, briefs, and other materials from court files (p. 224). In 60 of the 65 cases, the researchers were able to interview the attorneys for the principal parties (p. 225). The authors constructed a set of questions to be answered for each caselet, and reports were drafted by researchers under the direction of the principal investigators (pp. 224-25). These questions ranged from straightforward requests for information (for example, did the court retain jurisdiction over the case and for how long?) to more difficult qualitative evaluations of the claims and their resolution (for example, what was the degree of compliance with the court's order, and how novel was plaintiff's legal theory?). The authors present the results of the caselet studies in four chapters, each of which deals with a particular aspect of legitimacy or capability: "Principle/Policy Issues" (chapter 2), "Interest Representation Issues (chapter 3), "Fact-finding Capability Issues" (chapter 4), and "Remedial Capability Issues" (chapter 5). These chapters occupy about fifty pages and are crisply organized and written, with a "summary of findings" at the end of each.

The caselet analysis is supplemented by two detailed comparative case studies of legislative and judicial decisionmaking in the education sphere, and these two case studies take up more than twice as many pages as the more quantitatively oriented summaries of the caselet findings. The New York study concerns judicial and legislative responses to disputes between those seeking to increase the proportion of minority teachers and principals in New York City public schools and those committed to traditional hiring practices, seniority rules, and lay-off procedures. The second case study focuses on the recent bilingual-bicultural education controversy in Colorado, and the efforts of Mexican-Americans to alter the curriculum in public schools and to secure the hiring of more Mexican-American personnel. Four chapters are devoted to the case studies. They are rich in detail, and give the reader a feel for the complexity and subtleties of public interest litigation that, inevitably, cannot be obtained from the caselets. At the conclusion of each chapter, the authors analyze their research from the perspectives of principle/policy, interest representation, factfinding, and remedial issues, and, with few exceptions, the findings are broadly consistent with the findings for the caselet study.

The discussion of interest representation issues is, in some ways, the most puzzling aspect of the book. To the extent that all interested parties are represented in a public interest litigation, this would appear to reflect 
more on the capability of courts in adjudicating such matters than on the legitimacy of their doing so. That is true if one eschews utilitarian defenses of legitimacy, ${ }^{31}$ as the authors do. That is, if the court is aware of all of the benefits and costs of a decision, that decision is more likely to be correct and workable. The authors, on the other hand, argue that

[t]o the extent that courts today engage in . . . policy deliberations, the legitimacy of their actions is clearly undermined if (as under the traditional bipolar model) a limited number of litigants speak only for their particular interests and the courts receive no direct input concerning the perspectives or needs of the majority of citizens who might be affected by a wide-ranging decree. [P. 9.]

The authors' perspective on interest representation suggests theories of legitimacy apart from, and perhaps inconsistent with, the principle/policy dichotomy. Wider interest representation is relevant to legitimacy only if one believes that it enhances accountability (gives citizens something like the "last word") or that democracy entails giving minorities, underrepresented in legislative bodies, the opportunity to check majoritarian excesses through the judicial process. ${ }^{32}$ It is as if the authors are saying that courts should engage in principled decisionmaking, but if they depart from principle and fashion policy, that too is appropriate so long as courts consider all of the relevant interests and issues. Principled decisions, derived pursuant to an acceptable theory of judicial review, would not necessarily require broad interest representation, except insofar as principles may be accommodated or blunted by the likely consequences of their application.

A majority of the sixty-five cases in the sample were brought by minority individuals or groups, and these plaintiffs tended to prevail more frequently than "other" plaintiffs (p. 42). This is not surprising and is consistent with the view that judicial review protects interests thought to be at risk in pluralistic political processes, and that this is a legitimate function for courts. Nonetheless, as the authors admit (p. 36), the fact that minority groups frequently prevail in the courts does not necessarily mean that they do not have "fair access to the legislative process" (p. 36). Minority individuals and groups may turn to courts to maximize their chances of success even in circumstances where they are not frozen out of legislative processes. Further, the frequency of minority success in court tells us little about whether decisions are principled, and may run counter to the proposition that courts are aware of and respond to the "needs of the majority of citizens" (p. 9).

The treatment of other interest representation issues is provocative. In seventy-one percent of the cases, the plaintiffs requested certification of a class, but such certification was granted in less than half of the cases (pp. 42-43). In many cases, the court simply ignored or neglected these requests, and in a smaller percentage of cases the requests were denied outright, largely on technical grounds (pp. 42-43). Perhaps these statistics indicate a desire to represent broadly a large class, but as the authors correctly note, there is little evidence to suggest that judges are taking meaningful meas-

31. See generally Rhode, supra note 8 , at $1200-01$.

32. See, e.g., J. Choper, Judicial Review and the National Political Process 12970 (1980); J. ElY, DEMOCRACY AND DistruST (1980). 
ures in education cases to assure themselves of the representativeness of the plaintiff's claims (p. 38). Nor does pursuit of class action status necessarily suggest that public interest attorneys address their clients' preferences rather than their own philosophical predilections ${ }^{33}$ (p. 42). Courts, however, do tend to grant motions for joinder, intervention, or amicus status, and a majority of the cases involved multiple plaintiffs or defendants or groups. But courts did not encourage additional interests to participate, perhaps fearing that more participants would bring more complexity and delay to the litigation. The authors surmise that some interests and perspectives may not have been represented in these judicial proceedings ( $p$. 43). Whatever the consequences for Chayes' "new model" litigation, the authors reach the striking conclusion that legislatures and courts are equally adept or inept in terms of canvassing the different interests and issues in their decision making processes. ${ }^{34}$ And the nature of the controversy, "rather than [the] . . inherent institutional characteristics of the judicial or legislative forums," appears to determine the "breadth and depth of interest representation" (pp. 193-94).

With regard to factfinding capability issues, Educational Policy Making and the Courts should do much to dispel the myth that courts are less capable than legislative bodies in eliciting and analyzing factual information. When one reads the critical evaluations of the judicial process emanating from social scientists, one often imagines legislative bodies with extensive staffs drawn from eminent scholars of the Brookings Institution or the Rand Corporation and hapless courts mired in nineteenth-century rules of evidence and procedure.35 Attorneys work diligently to suppress or distort facts, the adversary process reveals only a small slice of the larger pie of information that should undergird decisions, and judges, untutored in statistics and social science methodologies, ignore the revealed truths of social science. Legislators, while imperfect, attend more closely to the facts, to the difficulties in implementing legal mandates, and to the relationships among policy areas. This "conventional wisdom" is contrary to the experiences of many who have participated in judicial and legislative proceedings.

Rebell and Block show that judges, particularly federal judges in public interest litigations, appear anxious to illuminate the issues with facts, the discovery process is usually quite extensive, and social scientists are frequently enlisted to offer testimony on the heady issues before the court. Without juries, there is a tendency to consider virtually any piece of evidence proffered by the parties. The parties, anxious to bolster their posi-

33. See generally Bell, Serving Two Masters: Integration Ideals and Client Interests in School Desegregation Litigation, 85 YALE L.J. 470 (1976) (discussing the potential conflict between the client's desires and the attorney's ideology); Rhode, supra note 8, at 1293-94.

34. The New York comparative study demonstrates that the same groups tend to participate in the legislative and judicial processes with respect to particular education issues, albeit minority groups were more influential in the court proceedings. Pp. 141-42. In Colorado, the comparative pattern of representation was the same, but in both forums the controversy was bipolar, largely pitting Mexican-American organizations and legislators against more conservative state officials and legislators. Interestingly, plaintiffs prevailed in the Colorado legislature and lost in federal court. The authors swallow hard and admit that the Colorado experience is an "exception" to their hypotheses about minority access to legislative bodies. P. 193.

35. See notes $2 \& 12$, supra. 
tions, happily seize on supportive social science research, often in a kneejerk manner. ${ }^{36}$ The authors have the impression that judges are quite attentive to the evidence, albeit they tend to challenge the efficacy or relevance of social science offerings. By way of contrast, legislatures often have inadequate staffs, and individual legislators may rush to judgment without being fully apprised of the issues and facts. In my experience, legislative hearings are more ritualistic than court hearings. Each side calls its witnesses, and testimony often is sought more to generate public and media support for or opposition to a bill than it is to inform decision making. Rather than crafty cross-examination, hostile witnesses may be greeted with silence or the $a b$ sence of members of the committee. In short, legislative proceedings may be as adversarial as court proceedings, and yet allow for a less orderly and less meticulous evaluation of the facts. This is not to say that either judges or legislators are adept at analyzing complicated facts (both often misinterpret social science findings), nor is it to suggest the legitimacy of courts exercising broad authority to settle policy disputes. But in an effort to lop off every head of the hydra-headed monster of judicial activism, critics too frequently distort this capability question in an effort to bolster their position on the legitimacy issue.

The authors are adept at demonstrating the comparative competence of courts with respect to factfinding issues, but they do so primarily through elaboration of caselets (pp. 45-46) or the longer case studies. ${ }^{37}$ In one case, for example, a cooperative discovery process generated all the data required for extensive social science studies by both parties. ${ }^{38}$ In particular, Rebell and Block argue that public agencies often felt an obligation to disclose information relating to broad questions of educational policy (p. 46). Further, as the New York case study demonstrates, judges are able to chide the parties into doing the leg-work to provide additional data necessary to the adjudication of the suit (p. 143). They suggest that courts compensate for their own lack of staff resources "by inducing the parties themselves to gather and submit the necessary information" (p. 143).

With regard to the treatment of social science evidence, the authors were unable to demonstrate that attentiveness to such evidence leads to reliance on it. Judges rarely based their decision on the testimony of social scientists (p. 37). Rather judges tended to employ various "avoidance devices" to resolve social science controversies. This is not surprising. Courts may have a healthy desire to rest their decisions on narrow grounds, leaving the broader issues to the political process. Citation to policy studies often leads

\section{See Yudof, supra note 8.}

37. The quantitative analysis yields precious few insights into the factinding process. For example, it is not clear what inferences one should draw from the statistics showing that formal discovery requests were made in 38 of the 65 cases and that courts ruled on the fairness of discovery in only 7 cases. P. 45.

38. Brown v. Board of Educ., 386 F. Supp. 110 (N.D. Ill. 1974), an intra-district school financing suit brought in Chicago, indicates how discovery may be used to aid in the decisionmaking process. The school district supplied plaintiffs with extensive records on expenditure patterns and staffing, and the plaintiffs used these records to provide the data for analysis by experts. The reports of plaintiffs' experts were turned over to the defendants, and defendants' experts reanalyzed the data and fashioned their own reports. The cooperative process of exchanging information led to agreement on a number of factual issues. P. 45. 
to charges of "social engineering." And, as Lindblom and Cohen, 39 among others, ${ }^{40}$ have noted, social science evidence does not resolve difficult normative questions, it supplements but does not supersede "ordinary knowledge," 41 and frequently it does not converge around a single perspective on a problem (that is, it poses more questions than it answers). ${ }^{42}$ The unwillingness to rely upon social science evidence may also indicate a devotion to principle, and the absence of relevant and persuasive research. Its actual infiuence may be indirect and incremental over long periods of time, as findings become a part of "ordinary knowledge."

Even if courts can be faulted for ignoring the findings of students of public policy, the shortcoming is widespread among public officials, including legislators. Consider what Rebell and Block have to say about the Colorado legislature's consideration of bilingual education issues. Expert testimony "primarily served a showcase function," which interviews with legislators confirmed "did not significantly shape the final outcome" (p. 194). Alas, Educational Policy Making and the Courts is fully consistent with the conclusion of Lindblom and Cohen that "in public policy making, many suppliers and users of social research are dissatisfied, the former because they are not listened to, the latter because they do not hear much they want to listen to."43

The interesting question, of course, is what inferences should be drawn from the authors' comparative analysis of factfinding and decisionmaking in courts and legislatures. Are courts "better" decisionmakers than legislative bodies? What does one mean by better? This critical point will be discussed more fully below. For present purposes it suffices to note that the authors perceive the judicial process as being more analytical, more attentive to the evidence, more systematic and more comprehensive. ${ }^{44}$

39. C. Lindblom \& D. Cohen, USAble KNowledge ch. 4 (1979).

40. See, e.g., Cahn, Jurisprudence, 30 N.Y.U. L. REv. 150 (1955); Yudof, supra note 8. See generally Education, Social Science, AND the Judicial Process (R. Rist \& R. Anson eds. 1972).

41. C. LiNdblom \& D. Cohen, supra note 39, at 35.

42. Id. at 47. See also Cohen \& Weiss, Social Science and Social Policy: Schools and Race, in Education, Social SCience, AND the Judicial Process, supra note 40, at 72.

43. Id. at 1 .

44. For example, in comparing the two forums in Colorado, the authors state that [t] he legislative experience in Colorado revealed a . . . pattern of lack of capacity for systematic fact-gathering or analytical fact analysis. Particularly striking in this regard is the contrast between the legislative deliberations and the Otero trial. ... The court's decision was, for the most part, attentive to the evidence and based on specific factual findings.

P. 194. And similarly, with regard to the New York legislature they observe that

[i] $t$ is often assumed . . . that legislatures, in comparison with the courts, possess an independent fact-gathering capability. Despite the New York State Legislature's highranking staff resources, it does not actually provide sufficient resources for substantive investigation and research. ...

Consequently, the legislature, like the court, was left to rely on the parties to supply basic data ....

... There was no pretense that evidence or expert testimony would be considered objectively and dispassionately. .... [T] he legislature, by the very nature of its political approach, is even more strongly inclined toward avoiding basic social fact issues [than are the courts]. As a result, in this case, no factual record that could be subjected to scrutiny was ever produced. Thus, comparing the legislature's and the court's capabilities . . . is 
The authors' empirical analysis of remedial capability issues is inconclusive. There is some evidence produced by the authors that courts are disinclined to grant broad, systemic reform decrees, and that judges attempt to adhere, as circumstances permit, to more traditional remedies (pp. 59-60). But surely the percentage of cases classified as involving reform decrees does not tell us very much about the intrusiveness of judicial remedies. And intrusiveness itself is a legitimacy question and not primarily a capability question. Finally, the dearth of meaningful measures of compliance tends to obscure the significance of empirical studies on a phenomenon as difficult to define as it is to observe. ${ }^{45}$ I am skeptical that one can determine the degree of compliance with reform decrees simply by interviewing the attorneys, seventy-eight percent of whom indicated that there was "complete compliance" with the court's order (p. 65).46

Nor is the absence of contempt citations, duly noted by the authors, a bellwether for compliance (p. 70). Plaintiffs and their attorneys may not have the continuing interest, the tenacity, or the resources to monitor compliance, and generally courts are dependent on the parties to produce evidence of compliance or noncompliance. Even the extended case study of the Chance litigation ${ }^{47}$ in New York indicates little more than that the court was a catalyst for change, ended the stalemate over personnel policies, and gave some direction to the negotiations taking place among the interested parties (pp. 118-19). If the court was not overly intrusive, it was not overly successful either (pp. 119, 146).

The most impressive aspect of Educational Policy Making and the Courts is its exploration in the case studies of how remedies were formulated in legislatures and courts. The authors, supporting Chayes' thesis, found that "the process of fashioning . . . a remedy was remarkably similar in the two forums" (p. 145). In the Chance litigation the fashioning of an appropriate "plan" was left to the parties, with the court mediating and

largely beside the point, simply because the legislature did not even purport to obtain and assess such data.

P. 144 (footnotes omitted). Thus, while the Rebell and Block research suggests that courts may be more capable of analyzing complex facts for decisionmaking, it also suggests that the primary distinction between courts and legislatures may be in their respective modes of solving policy problems. See generally Nagel, Book Review, 127 U. PA. L. REv. 1174 (1979) (arguing that Professor Tribe's rationalism should not be imposed on legislative decisionmaking).

45. Students of implementation theory endlessly debate the meaning of compliance and how it should be measured. See Clune \& Lindquist, What "Implementation" Isn't: Toward $A$ General Framework for Implementation Research, 1981 WIS. L. REv. 1044,1066-72. Perhaps if the clearly identified goal is to ensure that $30 \%$ of a school district's teachers come from minority groups, compliance is not difficult to ascertain (p. 65). But if the goal is to provide an "appropriate education" to handicapped students, if the legislature had latent or conflicting objectives, or if it intended to delegate broad authority while embracing only symbolic reform, the difficulties of ascertaining compliance are manifest. See, e.g., id.; Yudof, Legalization of Dispute Resolution, Distrust of Authority, and Organizational Theory: Implementing Due Process for Students in the Public Schools, 1981 WIS. L. REv. 891. Furthermore, defendants may comply with the letter but not the spirit of the law, e.g., by providing due process hearings to students charged with misconduct but not objectively and fairly considering the student's side of the story.

46. See generally Kirp, supra note 9.

47. Chance v. Board of Examiners, 330 F. Supp. 203 (S.D.N.Y. 1971). For the barrage of additional opinions by the district and appellate courts, see pp. 262-63 n.13. 
arbitrating disputes in those areas where they could not reach agreement. Similarly, the various interest groups negotiated with each other in the New York legislature, with the education committee breaking deadlocks (p. 145). In Colorado, representatives of the concerned groups met with key members of the legislature and hammered out the provisions of the bilingual education bill (p. 195). Since in neither forum did public officials take primary responsibility for the remedy, the authors conclude that, in general, there is no basis for assuming that courts are less able than legislatures to deal with complex remedial issues affecting large-scale public institutions. They are subject "to the same strengths and weaknesses" (p. 145).

Perhaps the critical point here is that at the remedial stage there is often no pretense, in either courts or legislatures, of principled decisionmaking in the sense that the remedy flows logically or analytically from the identified wrongs. The parties and interest groups, with different perceptions of the problem and of what needs to be done, may each attempt a logical approach to the remedial issues, but the final result is a function of bargaining and is unlikely to reflect a unitary analytical perspective. The only major distinction that the authors suggest is that the political bargaining process over judicial remedies is limited primarily to educational issues, whereas the legislature may engage in bargaining across many public programs, trading educational expenditures for reductions or increases in other service categories (pp. 195-96). ${ }^{48}$ They infer from this that the comprehensiveness of the legislative remedies in the education sphere "can be undermined as the process unfolds by the particularistic concerns of various political interests" (p. 195). Thus, according to Rebell and Block, the politics of remedies in courts blunts accusations of judicial intrusiveness and enhances the prospects for compliance with an order, whereas in legislatures a similar political process leads to a failure to scrutinize facts and compromises the comprehensiveness of the remedy. Ah, the perversity of politics.

\section{III}

In the last chapter, in what must have been an excruciating passage for Messieurs Rebell and Block to write, the authors candidly admit that their work may have proceeded on many wrong-headed assumptions (p. 215). Courts and legislatures are highly imperfect, but the available evidence does not suggest that courts are less capable than legislatures of canvassing the different interests, ascertaining the facts, interpreting social science evidence, devising remedies, or implementing their decisions. There is plenty of ineptitude in the public sphere; neither courts nor legislatures have a monopoly. But in examining judicial activism, how relevant are the capability issues? Should we be concerned with the relative absence of principle in legislative deliberations? In other words, have the issues in the debate over judicial activism been appropriately framed? Rebell and Block think not.

[T]he critical question, we now believe, is not whether the courts are "better" or "more capable" fact-finders or implementers of remedies than are legislatures, but whether particular aspects of social problems should be handled through the principled, analytic judicial process or through the 
instrumental, mutual adjustment patterns of the legislatures. [P. 215, footnote omitted.]

The legislative process, while not uninfluenced by principles (particularly the principles of individual members), ${ }^{49}$ is largely one of reconciling differences, of bargaining, of compromise. ${ }^{50}$ Information is highly relevant to the political process, "but such information need not be explored systematically nor related logically to the final outcome" (p. 208). The judicial process, on the other hand, aspires to analytic decisionmaking and to the justification of decisions in the light of principle, though the effort may fall short and politics and bargaining may influence the result (p. 208). If, as Alexander Bickel once opined, "[n]o good society can be unprincipled; and no viable society can be principle-ridden," 51 how should a democratic society go about assigning policymaking responsibilities?

This question is both broader and narrower than traditional inquiries into judicial activism. It is narrower in the sense that it assumes that principled judicial decisionmaking counters assertions that decisions of unelected federal judges, at least in constitutional litigations, are antidemocratic and hence illegitimate. ${ }^{52}$ This is hardly an incontestable proposition. Robert Nagel, for example, drawing on the philosophical writings of Michael Oakeshott, ${ }^{53}$ suggests that proponents of judicial review unconvincingly seek to justify the broad influence of constitutional law on public policy "by identifying rationalism with legitimacy, somewhat as the law generally tends to confuse good argument with good policy."54 Critical theorists, building on the nihilist elements of the legal realist tradition, see neutral principles and reasoned elaboration as subterfuges for accomplishing the objectives of liberal individualism. ${ }^{55}$ Legal theory allows judges to give their decisions a gloss of inevitability as a way of obscuring value judgments and choices. ${ }^{56}$

The question is broader in that even democratic societies must choose between analytic or rational modes of decisionmaking and what Lindblom and Cohen describe as the "interactive" method of addressing policy problems. ${ }^{57}$ There may be no neat dividing line between the two. There may be agreement that neither principle nor political bargaining should govern all manner of decisionmaking. There may be advantages in institutions with different modes of decisionmaking interacting with each other. But by some process (perhaps analytic, interactive, or both) particular types

49. See Brest, The Conscientious Legislator's Guide to Constitutional Interpretation, 27 Stan. L. Rev. 585 (1975). See generally D. Morgan, Congress and the Constitution (1966) (exploring the interaction of constitutional principles and politics).

50. See Nagel, supra note 44 , at 1191-93.

51. A. BiCKeL, supra note 24 , at 64 .

52. See id.

53. M. Oakeshott, Rationalism in Politics (1962).

54. Nagel, supra note 44, at 1183.

55. See Unger, The Critical Legal Studies Movement, 96 HARv. L. REv. 561 (1983).

56. See, e.g., Tushnet, Deviant Science in Constitutional Law, 59 TEXAs L. REv. 815 (1981); Tushnet, Truth, Justice, and the American Way: An Interpretation of Public Law Scholarship in the Seventies, 57 Texas L. Rev. 1307 (1979). But see P. Bobbitt, Constitutional Fate (1982).

57. C. Lindelom \& D. Cohen, supra note 39, at 20. 
of problems or issues will be thought to be better suited to one mode of problem solving or the other. ${ }^{58}$ And this is true even if federal judges stood for election every five years or if their constitutional decisions were subject to congressional revision.

Charles Lindblom and David Cohen, in their extraordinary work, Usable Knowledge,59 amplify many of these themes. They compare a policy process designed to enable policy makers to understand problems and to solve them through analysis with the interactive model, the stimulation of action "so that the preferred outcome comes about without anyone's having analyzed the given problem or having achieved an analyzed solution."60 There is no strict dichotomy, but the difference in emphasis is clear:

Strictly speaking, since people never stop thinking the alternatives are a frontal analytical attack on some identified problem, or interaction in which thought or analysis is adapted to the interaction and is therefore on some issues displaced by interaction. ${ }^{61}$

For example, even if each voter is well-informed and thoughtful, there is a difference between a single person or body deciding on who should be President, in the light of certain objectives and means-ends relationships, and the aggregation of individual preferences through the interaction of elections. The ultimate choice of a President, in a sense, may be "irrational," but in another sense the choice has simply been made by another means of decisionmaking. ${ }^{62}$ So, too, the behavior of buyers and sellers in the marketplace may solve allocation of resources problems, albeit resources may also be allocated by planners employing a "frontal analytical" approach.63

The problem is that those who aspire to rationality, whether judges or policy analysts, may tend to treat interactional politics or bargaining as illegitimate, as atavistic, or as simply perverse. ${ }^{64}$ Lindblom and Cohen quote

58. The distinction between interactive and rational decisionmaking has been discussed by a number of prominent scholars. Charles Lindblom, in a famous article, has compared the "science of muddling through" to goal-oriented, instrumental problemsolving. Lindblom, The Science of "Muddling Through", 19 PuB. AD. REv. 79 (1959). See also P. PETERSON, SchOOL Politics ChICAGo STYLE 128-39 (1976). Wildavsky argues that politics and markets are generally preferable to decisionmaking by experts. A. WILDAVSKY, SPEAKING TRUTH TO POWER: The ART AND CRAFT of Policy ANalysis (1980). Daniel Bell stresses that the "hopes of rationality" - "a rationality of means that are intertwined with ends and become adjusted to each other" - "necessarily falls before politics," bargaining among persons. D. BELL, THE Coming of Post-INDUSTRIAL SocieTY 365 (1976). Bell casts doubt on Max Weber's notion of a progression toward rationality in advanced industrial nations, and argues that society is rebelling: "rationality, as an end, finds itself confronted by the cantankerousness of politics, the politics of interest and the politics of passion." Id. at 350, 366. Michael Oakeshott suggests that "the objects of our desires are known to us in the activity of seeking them," and he decries the tendency to test and reject tradition and authority in the light of rationalist criteria. M. OAKeSHOTT, supra note 54, at 58. See also Nagel, supra note 44, at 1183. Oakeshott, like the others, is not rejecting common sense or purposeful behavior or thinking; rather he is attacking the modern tendency to substitute instrumental reasoning, embedded in systems of thought (whether law, political science, or policy analysis), for bargaining, tradition, and other less analytical modes of making policy decisions. See id. at 1183 .

59. See text following note 39 supra.

60. C. Lindelom \& D. Cohen, supra note 39, at 20.

61. Id. at 20.

62. Id. at 21-22.

63. Id. at 22 .

64. See W. LippMaNN, supra note 1, at 261; Nagel, supra note 44. 
numerous social scientists who view interactive problem solving as an abberation, regretting the unwillingness of legislators and other policymakers to listen to reason.65 Similarly, consider the symbolic hubris in the "rational basis test" under the equal protection clause, the notion, at least theoretically, that laws may be declared unconstitutional because of the lack of fit between means and ends. ${ }^{66}$ Why is it not sufficient that the enacted law is the one that commanded a majority, that adjusted individual and group interests in a tolerable way, that reflected bargain and compromise? Perhaps I have taken the rational basis test too seriously; for the test may veil other constitutional concerns. But the purported mode of analysis is troublesome. Surely, it is one thing to reserve expressly a place for principle, to invalidate a law because it discriminates by race or violates the free exercise of religion, and it is quite another to suggest that laws fail because they fall short of meeting the analytical standards of judges.

Educational Policy Making and the Courts falls perilously close to embracing the hubris of rationality, of treating political processes as a lingering perversion of collective decisionmaking. If legislators do not articulate clearly their objectives, if they respond to interests and not arguments, if they ignore information or do not consider it in a detached manner, it does not follow that the decision is necessarily "wrong" or inferior to judicial decisions. ${ }^{67}$ Legislatures, of course, are not mystically endowed with wisdom. Some legislative decisions may be worse than others; sometimes there may be a failure to recognize and address constitutional concerns; ignorance or prejudice may prevail. 68 But there are advantages to "legislative 'irrationality." "69 Principle may legitimate decisions, but so may politics. And "politics is haggling, or else it is force."70

To some extent, Rebell and Block recognize these points. When all is said and done they are uncomfortable with some of the inferences that may be drawn from their study of comparative institutional capabilities. They have disarmed some of the critics of judicial activism, they have shown that courts are not bumbling fact-finders incapable of recognizing diverse interests or devising comprehensive remedies, but in so doing they have raised other issues. If courts bargain over remedies like legislatures, does this not

65. C. LINDBlom \& D. Cohen, supra note 39 , at ch. 3.

66. Nagel, supra note 44, at 1189-91. See generally P. Brest \& S. Levinson, Processes of Constitutional Decisionmaking 549-76 (2d ed. 1983).

67. Nagel, supra note 44, at 1191-92. (1980).

68. See generally Bice, Rationality Analysis in Constitutional Law, 65 MiNN. L. REv. 1

69. Nagel, supra note 44 , at 1192.

If values need not be formally articulated and consistently pursued, legislators can serve many interests at once. . . . Legislators are free to respond to intensity as well as articulateness . . . . Even if no objective is fully achieved, many groups can be partially satisfied and can therefore be expected to retain some sense of loyalty to the governmental process. Because negotiation and trading "across substantive fields" are encouraged, the hard sacrifices that different allocations of resources require are implicitly recognized . . . . Because compromise is necessary and abstract argument is of limited value, groups are encouraged to find the common ground in their positions, rather than to insist on apparently irreconcilable differences of principle.

Id. at 1192-93.

70. D. BELL, supra note 58 , at 365. 
establish capability at the price of undermining legitimacy? Paradoxically, the more competent courts are in adjusting interests, the more they may depart from the principled decisionmaking that is supposed to distinguish them from legislative bodies. If legislatures do not weigh the facts and examine issues analytically, does this mean that courts are superior decisionmakers? But this conclusion undercuts democratic theory and elevates a new breed of philosopher kings, giving them unacceptable powers in a democracy.

In the end, the authors do not claim that their study will change many minds on the issue of judicial activism (p. 216). Like Antoine de Saint Exuperry's Little Prince on the fourth planet, they understand that counting the stars does not yield their secrets or establish ownership. ${ }^{71}$ They see a need to reformulate the issues and to probe the boundaries of different modes of problem solving. If Rebell and Block did not grasp this point when they began this book many years and drafts ago, neither did many other legal scholars. And we should be grateful for their contribution; for they have laid the foundation for the work that needs to be done.

71. A. de Saint Exupéry, The Litrle Prince ch. 13 (K. Woods trans. 1943). 


\title{
THE TWENTIETH-CENTURY PRIMACY OF STATUTORY LAW
}

\author{
Albert Tate, Jr.*
}

Dealing with Statutes. By James Willard Hurst. New York: Columbia University Press. 1982. Pp. viii, 140. $\$ 15$.

A legal professional - practitioner, judge, or academic - tends to focus research and reasoning upon judicial decisions. Even if the issue concerns the application of a statute, usually the exposition primarily relates to the enactment as refracted through prior cases interpreting and applying it. Partly this is due to our Anglo-American legal heritage, where, prior to the twentieth century, law primarily evolved through the decisions that were the foundation and fabric of the common law. The case method of instruction, common to our legal training, perhaps contributes to this persisting concentration on the development of legal principle in judicial decisions. Similarly, constraints of stare decisis often pragmatically require us to look first at the cases interpreting a statute rather than to the statute itself for its meaning and present application.

Professor James Willard Hurst's Dealing with Statutes is a thoughtful analysis of the central importance of statutory law in the twentieth-century United States. The three essays comprising this relatively brief work ${ }^{1}-$ "Legislative Process," "The Interpretation of Statutes," and "The Constitutionality of Statutes" - do not attempt to do more than present a broad overview of the role of statutory law and of judicial interaction therewith. Fundamental principles are restated with insight, and critical points of possible dysfunction are perceptively noted. Most probably, these theoretical propositions, critiques and insights have previously been stated elsewhere by Professor Hurst and others, but the importance of Dealing with Statutes lies in its having concentrated in intense and brief focus the central modernday issues of legislative function and of judicial function with regard to legislation. The truths it speaks may be self-evident, but I, at least, recognized some of them as self-evident only after Hurst's skillful and scholarly analysis.

The first essay, "Legislative Process," affords penetrating insight into the fundamental essence of legislative power, including its unique and pervasively controlling role in affording social catharsis and regulation for the

* Circuit Judge, United States Court of Appeals for the Fifth Circuit, New Orleans, Louisiana.

1. The essays in the work were derived from the 1982 James S. Carpentier Lectures delivered at Columbia University by the author, who is the Vilas Professor of Law at the University of Wisconsin. Professor Hurst is also the author of several important works on the social history of law, including: THE GROWTH OF AMERICAN LAW (1950); LAW AND ECONOMIC Growth (1964); LAW AND Social ORDER IN THE UNITEd STATES (1970); A LEGAL History of MONEY IN THE UNITED States, 1774-1970 (1973); The Legitimacy OF THE Business Corporation IN the LAW OF the UNITEd States, 1780-1970 (1970). 
ever more complex and congested society of twentieth-century America. Initially, Hurst notes that "[c]entral to the practical importance of legislative process is the range of jurisdiction of legislatures over parties and subject matter" (p. 2), especially as contrasted with the limits of initiative in lawmaking that hedge executive and judicial agencies. "The open-door principle governing legislative jurisdiction gains emphasis from the fact that there are almost no judicially enforceable procedural limits on how the legislature does its business" (p. 3) - what facts it does or does not hear, what subject matter it does or does not consider, what notice or opportunity to rebut it does or does not give. Hurst summarizes:

[W]ith all the limitations, imposed by the realities of unequal means, knowledge, and skill of petitioners, the open-door character of legislative jurisdiction has given a distinctive place to legislative process. In the country's experience statute law has had special importance in giving content to public policy and adapting the legal social order to changing currents of interest and circumstances. [P. 4.]

The first essay analyzes the "unique array of legislative powers" (i.e., defining standards and rules; taxing, borrowing, and spending; creating new forms of governmental and private organization; and investigating) and offers a perceptive but brief historical perspective on the changing use of these powers in performing the legislative role from our nation's earliest days to the present. He also reminds us that, due to the roles of legislative oversight and budget committees, "legislation is in important measure a continuing process" (p. 17). The statutes themselves set limits on the jurisdiction and procedures of executive agencies, and "in large part . . . have set the terms on which judges may review the procedures and substance of executive and administrative action" (p. 17). Hurst points out that in modern America, "legislators and the executive and administrative officers in central and in local government to whom they delegated power produced a body of service and regulatory law that dwarfed the common law performance" (p. 27).

The concluding portion of the first essay is in the nature of a paean to the central role of the legislative process - that process of harnessing collective effort and balancing conflicting interests for the purposes of establishing both broad principles of public policy and also particulars of regulation essential to the vitality and social order of a constantly evolving society. Hurst concludes:

The need to effect a proper balance between responsibilities to make general policy, to respond by proper delegation to needs for more particularized development of policy, and to exercise effective supervision of executive and administrative agencies, has posed constant challenges to twentieth-century legislators . . . . [T] he problems of relating general and particular policy are fixed firmly in the structure of the legal and social order. These problems will not go away. They present the principal challenge of the times to the conscience, skill, and experience of legislative lawmakers. [Pp. 28-29.]

The second essay, "The Interpretation of Statutes," while maintaining the broad philosophical perspective of the first, addresses more mundane and practical concerns, as indicated by the essay's subheadings: "The Intention of the Legislature," "Legislation as Product of a Continuing Pro- 
cess," "Form and Substance in Statute Law," and "Rules of Construction." The essay is not, however, a trite restatement of prior propositions or debates but rather, in this reviewer's opinion, an original and forceful exposition of the few most central and controlling principles that, explicitly or not, motivate the approach of a twentieth-century American court in assigning meaning to and devising application of a statute.

By way of introduction, Hurst rejects (for convincing reasons) the thesis of Max $\operatorname{Radin}^{2}$ and others that it is a judicial fiction to assign any specific legislative intent to the enactments of a multi-membered, often inattentive, committee-dominated legislature. First, while a legislature may not have particular applications in mind, legislation undoubtedly involves "general goals" and a "general range of means" (p. 36) directed at courts or other agencies to assist them in enforcing the statute and its ends. Second, while a "statute is normally the product of focused effort and detailed attention of a relatively few individuals," and while the "committee is the key workplace of the legislature," the work product is, nevertheless, designed for acceptance by the entire body (p. 37). Although "normally the role of the general membership is a cautionary, residual one, [which promotes] responsible work by the specialists," "the limited circle that works up the bill must make such choices and adjustments as they calculate will pass muster before the larger body or not unduly arouse opposition there" (p. 37).

Professor Hurst rather eloquently concludes:

[A] statute embodies a choice of values carrying obligations on those within its governance, backed by the force of the state. Under our constitutional arrangement of official powers, legislators may legitimately thus set guiding or limiting frames of action for other people. Because the statute's function is to make authoritative value determinations, fulfillment of the function is impossible without inquiry as to what values and what order of values the legislators had in mind. Inevitably those who put statutes to use must exercise considerable discretionary judgment on specifics that the legislators have not directly resolved. Also, they must exercise cautious wisdom in consulting materials outside the statutory text. But in the end the presence of the statute tells them that they deal with an area of public policy where not their value choices but those of a distinct body are to set the course. [P. 40.]

It seems to me that few should disagree with these observations.

I must add, however, that the problems of statutory interpretation most troublesome to me, as a federal appellate judge for the past three years, are not those arising from legislative wording or intention, but rather how a court, bound by stare decisis, can reconcile legislatively expressed intent with the judicial encrustations that have added dimension to the original enactment beyond those initially contemplated by its enacted wording. ${ }^{3}$ of

2. See Radin, A Short Way With Statutes, 56 HaRv. L. Rev. 388, 406-12 (1942); Radin, Statutory Interpretation, 43 HARV. L. REV. 863, 869-72 (1930).

3. See, e.g., United States v. M/V Big Sam, 681 F.2d 432 (5th Cir. 1982), petition for rehg. and suggestion for rehg. en banc denied per curiam, 693 F.2d 451, 452 (5th Cir. 1982), where application of a provision of the Federal Water Pollution Control Act Amendments of 1972, 33 U.S.C. $\S \S 1251-1265,1281-1293,1311-1328,1341-1345,1361-1376$ (1978), was rather clearly expressed in unambiguous statutory language. Nevertheless, identical statutory language directed at a different but related situation had previously been interpreted otherwise by a prior decision, and four judges dissented from the denial of an en banc rehearing in the view that 
course, the brevity and breadth of the work precludes discussion of such particularized problems, as well as of the rather common situations where, in truth, there is no easily discernible legislative intent extending to unforeseeable circumstances that inevitably reach the court. 4

The remainder of this second essay on statutory interpretation is the best single treatment $I$ have read of twentieth-century judicial approaches. Partly, perhaps, because of succinctness, Hurst's insights have crystallized my own gropings toward an articulated theory over twenty-eight years of appellate service. Hurst barely refers to the traditional maxims, which are in fact usually spoken of (if at all) as if they prescribed the result. Actually the often contradictory maxims merely help describe an asserted process of reasoning by which the judge, independently, has determined the proper meaning and application of the statute to the case before him. ${ }^{5}$

Having made his point as to the importance of acknowledging the criterion of legislative intent, Hurst suggests that of second importance is "the need to recognize that if legislation becomes a living part of social experience typically it does so as the result of a continuing process, only part of which is represented by putting words into a statute book" (p. 40): "The statutory text is central and commands deference. But to grasp the full reality of its impact we should see it as part of a flow of policy-making activity" (p. 41). As he observes, modern-day courts do not regard legislation as an extraneous growth in the common law garden that needs cropping and weeding. Rather, in an effort to determine and enforce the legislative intent, and responding to the changes in the legislative process in this century, today's courts tend to emphasize and give weight to four principal factors: (1) the particular legislative history of the enactment before it, with especial reference to legislative committee reports and floor-explanations and to amendments or changes in the bill between its introduction and enactment, but with appropriate credibility-discount as to other floor statements or committee testimony; (2) the pattern of succession of other statutory enactments in the particular field, with the guidance as to the delineation of public policy and consequent interpretation of the present statute furnished by successive statutes over the years; (3) the bearing of general sectors of legislation on the meaning to be given a particular act, since "the content of public policy may grow by accretion of statutory precedents in a fashion analogous to the growth of common law" (p. 45); 6 and (4) the practical, consistent administrative construction given the statute by the officials charged with its administration, thus recognizing that "a statute of broad reach is not a finished product the day the legislature adopts it" (p. 45). Hurst summa-

this prior interpretation had, so to speak, frozen the legislative intent for purposes of subsequent interpretation of the related provision.

4. See, e.g., Tate, The Judge's Function and Methodology in Statutory Interpretation, 7 S.U. L. REv. 147, 158-59, 167-69 (1981); Tate, The "New" Judicial Solution, 54 Tul. L. REv. 877, 888-90, 897-900 (1980).

5. See Llewellyn, Remarks on the Theory of Appellate Decision and the Rules or Canons About How Statutes Are to be Construed, 3 VAND. L. REV. 395, 401-06 (1950).

6. "Statutes dealing with a variety of subjects may begin to cluster around some common value judgment. Recognizing this reality, a court is warranted in finding evidence of legislative intent under a given act by reference to what legislators have done regarding like subjects under other acts." P. 45. 
rizes "these several lines of doctrine and practice" by stating that "[t]he statutory text is basic and central. But if law is to be a vital force in society, the text usually must be seen as part of a flow of policy-making activity that originates before the text is voted and continues after it is on the books" ( $p$. 46).

Hurst also perceptively discusses the hard problem that sometimes arises in reconciling the express wording of a statute (its form) and an application thereby directed that seems contrary to or not contemplated by the statutory choice of policy-values (the substance). Admitting the theoretical difficulty of performing this reconciliation, Hurst suggests that on the rare occasions when this is appropriate the courts may be recognizing the reality that legislatures "[n]ormally . . . act for limited, or at least specialized ends" (p. 52); therefore, it may sometimes be appropriate to go behind the words of the statute to the narrowed legislative intent as reflected by the legislative history. But this admission is appropriately accompanied by a notation of the cautionary limitations (burden of persuasion, alleged ambiguity of statute at least as applied, etc.) that demonstrate why, for most practical purposes, this approach to statutory construction is discussed more often in a classroom than in a courtroom. ${ }^{7}$

The final section of this essay on statutory interpretation, "Rules of Construction," clears away much dead-maxim timber and charts workable rules that are in fact utilized by modern-day courts. These rules are of two natures: those that best reflect the realities of the legislative process as most consistent with the deference owed the legislature in policy-making, and those that explicitly endorse broad value preferences not tied to any particular statutory subject matter. The former "rules of construction that reflect familiar patterns of communication or operations in the legislative process" (p. 62) include: customary word usage, indicating either broad or particular applications; statutory context - "we read particular words or phrases in the light cast by other parts of the same statute" (p. 59) - including exception clauses; and material in other actions dealing with the same subject or the same subject matter - since typically the legislature "is likely to deal at one point of time with less than the whole" - so that "legislative intent may emerge in full definition only through a succession of acts" (p. 61). Of the latter type of rules declaring broad policy preferences, Hurst deems worthy of mention only the rule requiring strict construction of penal statutes and (surprisingly, at least initially) "the rule (presumption) that a statute in derogation of common law should be construed as not intended to change common law unless that intent is made plain" (p. 62).

The essay emphasizes, however, that these "rules" are only presumptions, casting the burden of persuasion upon those attempting to read a statute broadly or to overturn the common law. The presumption may be rebutted, for example, by the legislative history or by the explicit choice of policy-values represented by the enactment as a whole. After a lifetime of scoffing at the rule that a statute in derogation of the common law should

7. Despite my deprecating remarks, in my own judicial experience I have noted some instances where statutory words literally applied to a changed social or statutory context produce results obviously beyond the contemplated legislative intent, so that there is a substantial issue whether statutory meaning should be frozen to the original context, and statutory language not literally applied to the changed circumstances. See, e.g., sources cited in note 4 supra. 
be strictly construed, I find myself persuaded, somewhat reluctantly, by Professor Hurst that this construction maxim, if not mechanically applied, represents the realities of the legislative process. The legislature normally considers only one aspect of a problem, and may not in the least consider how its actions might disturb accepted jurisprudential rules related to but beyond the scope of the problem alone addressed.

To use an example from my recent experience, the courts, by considering this principle, might have avoided some of the confusing, laborious, and conflicting opinions associated with the 1972 amendments to the Longshoremen's and Harbor Workers' Compensation Act. ${ }^{8}$ Prior to the 1972 amendments, coverage of the Act was restricted to injuries on the navigable waters; moreover, all injuries to amphibious non-seamen on the navigable waters were regarded as occurring in maritime employment. 9 This clear delineation had been arrived at, however, only after more than thirty years of litigation, during which it was often uncertain whether a land-based worker injured on the waters was required to obtain relief through federal or state compensation remedies. ${ }^{10}$ According to rather specific legislative history, the 1972 amendments were designed solely to expand coverage to include maritime workers injured in areas adjoining the navigable waters, as well as actually upon them; nevertheless, in addition to describing this expanded "situs," it became necessary to define those covered by the act as only those "engaged in maritime employment" who were injured on the expanded situs. ${ }^{11}$

The issue then surfaced as to whether the new statutory "status" test of maritime employment excluded amphibious workers injured on the water (and, by pre-1972 jurisprudential definition, in maritime employment because of the navigable water situs). Courts laboriously wrestled with the application of this new statutory test in that context. ${ }^{12}$ Finally, in its 1982 en banc decision in Boudreaux v. American Workover, Inc. ${ }^{13}$ the Fifth Circuit, taking into consideration the complete absence of any contrary legislative intent and the limited and specific changes expressly intended by the Congress, concluded that the new legislative language was not intended to change the prior concept of on-water injury to any amphibious worker as being in maritime employment for purposes of compensation coverage by the Act. ${ }^{14}$ It seems to me that much of the confusing, cumbersome, and conflicting judicial reasoning might have been avoided, had we followed Professor Hurst's analysis based upon the realities of the modern legislative

8. 33 U.S.C. $\$ \S 901-950$ (1978).

9. See Calbeck v. Travelers Ins. Co., 370 U.S. 114 (1962).

10. For a summary, see Boudreaux v. American Workover, Inc., 680 F.2d 1034, 1043-45 (5th Cir. 1982) (en banc) cert. denied, 51 U.S.L.W. 3549 (U.S. Jan. 25, 1983) (No. 82-605).

11. 33 U.S.C. $\& 902(3)$ (1978) (as amended in 1972). The legislative history is described in Boudreaux, $680 \mathrm{~F} .2 \mathrm{~d}$ at $1045-48$.

12. See Boudreaux, 680 F.2d at $1045-48$.

13. 680 F.2d 1034 (5th Cir. 1982) (en banc), cert. denied, 51 U.S.L.W. 3549 (U.S. Jan. 25, 1983) (No. 82-605).

14. To be fair, the Second Circuit reached a conclusion contrary to that of the Fifth Circuit in Boudreaux; however, the Supreme Court has subsequently adopted the view of the Fifth Circuit. See Churchill v. Perini N. River Assocs., 652 F.2d 255 (2d Cir. 1981), revd., 51 U.S.L.W. 4074 (U.S. Jan. 11, 1983) (No. 81-897). 
process - that we should presume that legislation directed at a narrowed issue was not intended to change the pre-existing jurisprudential rules on related topics unless that intent is made plain.

This essay concludes with the following excellent summary of the approach of modern-day courts to statutory interpretation:

If we regard together uses judges make of statutory text, legislative history, and general rules of construction in the second half of the twentieth century, one approach is clearly dominant, standing in sharp contrast to nineteenth-century treatment of legislation: The twentieth-century emphasis is on coming to a specific focus on a given statute in its full-dimensioned particularity of policy, rather than emphasizing material or values not immediately connected to that enactment. Courts now seem usually to strive to grasp the distinctive message of statutory words, taken in their own context, with reference to the documented process that produced that particular act, including legislative history deserving credibility, and policy guides supplied by the legislature's successive development of the given policy area and related areas. The twentieth-century emphasis thus is not on broad, standardized formulas, but on custom-built determinations, fashioned out of materials immediate and special to the legislation at issue. It is an approach both more pragmatic and more deferential to the functions of courts under the separation of powers. [P. 65.]

The final essay, "The Constitutionality of Statutes," "examines key procedures for achieving the necessary adjustments between constitutional grants and limits and exercise of legislative will and choice in making particular public policy" (p. 68). The essay is an invaluable analysis of current theory and practice with regard to judicial review of the constitutionality of statutes. The concern is not with substantive content of constitutional law but rather "with the criteria and procedures developed to deal with special problems involved in analyzing, briefing, arguing, or deciding questions about the constitutionality of legislative action" (p. 68).

Aside from a brief discussion of the institutional roles of legislators and judges, the essay concentrates on the presumption of constitutionality. Relying in part upon an early analysis by Judge Learned Hand, Professor Hurst points out that a statute typically (if not always explicitly) embodies (a) a goal of what ought to be done for the general interest, based on (b) the legislature's actual or supposed appreciation of the present facts that justify this end; together with (c) a choice of means of how the goal should be accomplished, based (d) (similarly to (b)) upon facts of human behavior or human experience relevant to making judgments about the legislative choice of ends and means. Since the court is merely a reviewer and must constitutionally defer to the legislative originator's choices, those attacking the constitutionality of a statute must, in effect, bear the burden of persuasion that under no reasonably contemplated set of facts can the legislature's choice of ends and means be regarded as other than arbitrary. In discussing the application of the presumption, the essay succinctly summarizes its base and reach, the weight of the burden of persuasion to be put on the challenger, the scope of the required rebuttal of the presumption, the influence of the state of the record, and the practicability of meeting the burden of persuasion on issues of fact or of value relating to the enactment's constitutionality. This relatively brief essay is a primer of central issues that should 
almost be required reading for legislators, advocates, or judges concerned with issues of the constitutionality of statutes.

The final portion of this essay concerns the development in the latter portion of this century of doctrines of stricter scrutiny of statutes when constitutionally preferred values are at issue, such as those that make race a criterion to the detriment of a disadvantaged class, those that hinder or limit the right to vote, those that explicitly or in practice discriminate against interstate commerce, those that burden processes of public communication, and those that intrude on areas of life that individuals value as of private rather than public concern (such as affairs of the family, childbearing, and freedom to practice religion). The six pages (pp. 99-105) that discuss and critique the workings of preferred-value review once again, as throughout the work, afford insights, perspective, and intelligent appreciation of the central issues and values of the subject.

The thrust of this essay on judicial review emphasizes that judges in this portion of the century have acted with restraint. Even taking into account the courts' preferred-value review (to some extent a creation by the judiciary of values that it perceives as constitutionally preferred), the relative role of the judge in public policy is far from "judicializing the law of the late twentieth century" (p. 106). In conclusion, the essay brings into perspective the apparent surge in judicial scrutiny of the constitutionality of statutes that arguably impinge on preferred values:

First, judges have not been the only actors on behalf of these values.

Tardy and cumbersome as it tends to be, the legislative process has also contributed, as in legislation increasing access to public records, regulating use of money in politics, and enlarging legal protection of civil rights. Second, save in the limited instances in which constitutional rules apply, the presumption of constitutionality provides the frame within which the validity of the great bulk of legislation is judged; important as they are, preferred-value categories apply only to a small part of the whole body of statute law. Finally, contests in court carry drama which encourages people to exaggerate their range and incidence. The overwhelming bulk of statute law and the delegated legislation that exists within a framework of statute law never comes into any kind of constitutional litigation. [P. 106.]

The three essays in Dealing with Statutes, brief but broad in content, synthesize with perceptive evaluation the current roles of the legislature and the courts in the enactment and application of statutes. The work would be invaluable if it did no more than sum up so succinctly the central thrusts in the twentieth century toward the primacy of statute law and the underlying reasons for the modern changes in the treatment and interpretation of statutes by the courts. The essays, however, are not only a summing-up and critique of this nature and of the relevant considerations and key problem points of the subject. In this reviewer's opinion, Dealing with Statutes, with its fresh insights based upon the realities of today's legislative and judicial processes, convincingly discards theoretical approaches mooted by modern circumstances and in their place furnishes a theoretical framework for the understanding of the ongoing relationship between enacted words, legislatures, and courts that is based upon how and why twentieth-century legislators and judges actually act in our always-changing society. 


\title{
COMMON SENSE ABOUT THE AGE OF STATUTES
}

\author{
Steve MacIsaac*
}

A Common Law for the Age of Statutes. By Guido Calabresi. Cambridge: Harvard University Press. 1982. Pp. 319. \$25.

\author{
"An Act of Parliament can do no wrong, though it may do several things that \\ look pretty odd."
- Holt, C.J., City of London v. Wood, 88 Eng. Rep. 1592, 1602 (K.B.
1701)

Professor Calabresi's book, A Common Law for the Age of Statutes, tentatively formulates a doctrine that he believes will provide some relief for a legal system that is - to use his colorful phrase - "choking on statutes" (p. 1). Actually, "gagging" might be a catchword more appropriate to Calabresi's perception of the problem, because his concern is not with the sheer volume of legislation but instead with the unpalatable task that courts face when they are forced to apply obsolete or anachronistic statutes. He maintains that courts have resorted to a variety of techniques - some valiant, some disingenuous, all ultimately ill-advised - to cope with senile statutes, and argues that frank recognition of a judicial power to update or force legislative "reconsideration" of obsolete statutes is the only appropriate solution. The proposition that courts should actively prod legislators into facing up to their "majoritarian responsibilities" is decidedly upbeat in an era that finds many commentators fretting about how far legislatures can limit the courts. ${ }^{1}$ As a result, the book is certain to be widely read. Critical response is equally certain: Calabresi writes and thinks in grand style, and so many of the concepts central to his doctrine are defined vaguely and some questions he "does not take too seriously" will be thought by others crucial to the doctrine's legitimacy. ${ }^{2}$ The book is therefore likely to spark a dialogue in the legal community, a prelude to what Calabresi hopes will eventually be a dialogue between the courts and the legislatures. ${ }^{3}$

* B.A. 1978, Wayne State University; J.D. 1982, University of Michigan. Law Clerk to the Hon. James L. Oakes, United States Court of Appeals for the Second Circuit. - Ed.

1. See, e.g., Sager, The Supreme Court, 1980 Term - Foreword: Constitutional Limitations On Congress'Authority to Regulate the Jurisdiction of the Federal Courts, 95 HARv. L. Rev. 17 (1981).

2. See Mikva, The Shifting Sands of Legal Topography (Book Review), 96 HARv. L. REv. 534,534 (1982) (stating that Calabresi's doctrine "patently confuse[s] articles I and III of the Constitution").

3. A recent outpouring of reviews already has made something of a start on such a dialogue. See Coffin, Book Review, 91 YALE L.J. 827 (1982); Cox, Book Review, 70 CALIF. L. REV. 1463 (1982); Hurst, Book Review, 67 MINN. L. REv. 563 (1983); Hutchinson \& Morgan, Book Review, 82 Colum. L. Rev. 1752 (1982); Mikva, Book Review, 96 HARv. L. Rev. 534 (1982). 
The book opens with a prolegomenon that outlines the parameters of the problem, the responses Calabresi believes have failed, and his conclusion that "we are already doing, badly and in hidden ways, much of what this 'radical' doctrine [would] allow[ ]" (p. 7). He identifies "legislative inertia" - the tendency of legislatures to leave old laws intact despite changed circumstances that render the original rationale inapposite or the statute's operation perverse - as the source of the problem. The result, according to Calabresi, is that "getting a statute enacted is much easier than getting it revised" (p. 6). He concludes that legislative inertia has upset an idealized balance between continuity and change, a duet between the courts and legislatures synchronized with the essentially conservative American tradition of law revision. The remainder of the book is divided about equally between examining and rejecting approaches Calabresi views as flawed attempts to recapture this balance, and exploring how a doctrine that would allow courts to update statutes could be applied and how it would be limited. The section that will be of most interest to many readers - the defense of the doctrine's legitimacy - lies between Calabresi's descriptions of what is and what might be.

\section{I}

Various scholars and jurists have expressed alarm at what the idiot wind of time does to statutory law. In addressing this problem Calabresi joins a distinguished line of individuals that includes Sir Francis Bacon, ${ }^{4}$ Roscoe Pound, ${ }^{5}$ Cardozo, ${ }^{6}$ and, more recently, Judge Henry Friendly ${ }^{7}$ and Grant Gilmore. ${ }^{8}$ But those who are not convinced that statutory obsolescence is the problem Calabresi thinks it is may be skeptical of his view that courts have taken "flight to the constitution" to eliminate statutory deadwood. He argues that courts have been tempted, in their desire to treat like cases alike, to use an equal protection approach to invalidate old statutes based on rationales or presumptions that now seem either outdated or constitutionally doubtful. The idea is provocative, and his discussion of the few cases he sees as illustrative of the trend is interesting, but there may be less here than meets the eye. Calabresi may be unusually prescient in spotting a trend, but his fear that courts will overextend themselves and thereby endanger "core" constitutional rights in their attempts to invalidate old statutes seems overdrawn. ${ }^{9}$ In the absence of a constitutional principle that would distin-

4. F. BaCON, An Offer to the King of $A$ Digest to be Made of the Laws of England, in LAW TRACTS 15, 20 (1737) ("The laws of the most kingdoms and states, have been like buildings of many pieces, and patched up from time to time according to occasions, without frame or model.")

5. Pound, Anachronisms in Law, 3 J. AM. JudicATURE Socy. 142 (1920).

6. Cardozo, A Ministry of Justice, 35 HaRv. L. REv. 113 (1921).

7. H. FrIENDLY, The Gap in Lawmaking - Judges Who Can't and Legislators Who Won't, reprinted in BENCHMARKS 41 (1967).

8. G. Gilmore, The Ages of AMERican LaW 95-97 (1977).

9. See Railway Express Agency, Inc. v. New York, 336 U.S. 106, 112 (1949) (Jackson, J., concurring) ("IInvocation of the equal protection clause [as opposed to the due process clause] does not disable any governmental body from dealing with the subject at hand. It merely means that the prohibition or regulation must have a broader impact."); Mikva, supra note 2, at 537. But see Westen, The Empty Idea of Equality, 95 HARv. L. REv. 537, 587-92 (1982). 
guish between statutes on the basis of age alone, ${ }^{10}$ it is unclear that the contours of "current" constitutional doctrine are likely to be distorted by the tug of old statutes on the judicial conscience. Certainly the cases rejecting constitutional challenges to recent legislation shielding select groups from tort liability do not support such a thesis. ${ }^{11}$

Calabresi also rejects the possibility of remedying obsolescence through the use of doctrines that, following Bickel, ${ }^{12}$ he lumps under the rubric of "passive virtues." His primary argument here is that the techniques Bickel championed would lose their "true meaning" if they were used to force legislative reconsideration of statutes that, although obsolete, present no constitutional difficulty. Cynics, of course, might question what would be lost by "abusing" a doctrine like delegation of powers that is, at least at the federal level, virtually a dead letter. ${ }^{13}$ One also wonders whether other ap-

10. Calabresi hints at such a principle, but does not develop it:

The notion is that there may be some issues as to which the very structure of our government, or the requirement of a republican form of government, or concepts of due process and equal protection, demand a current answer by a relatively majoritarian body although there may be no constitutional requirement as to what the answer must be.

P. 266 n.99.

11. A number of states passed statutes in the 1970s in an attempt to slow the increase in health care costs generally attributed to large malpractice awards. Typically, these statutes required would-be plaintiffs to submit their claims first to arbitration panels - thus giving rise to right-to-jury challenges - and some of them imposed an upper limit on the amount that plaintiffs could recover. These statutes have generally been upheld. See, e.g., Eastin v. Broomfield, 116 Ariz. 576, 570 P.2d 744 (1977); Carter v. Sparkman, 335 So. 2d 802 (Fla. 1976), cert. denied, 429 U.S. 1041 (1977); Everett v. Goldman, 359 So. 2d 1256 (La. 1978); Maryland v. Johnson, 282 Md. 274, 385 A.2d 57, appeal dismissed, 439 U.S. 805 (1978); Paro v. Longwood Hospital, 373 Mass. 645, 369 N.E.2d 985 (1977); Prendergast v. Nelson, 199 Neb. 97, 256 N.W.2d 657 (1977); Halpern v. Gozan, 85 Misc. 2d 753, 381 N.Y.S.2d 744 (Sup. Ct. 1976); Parker v. Children's Hospital, 394 A.2d 932 (Pa. 1978); Strykowski v. Wilkie, 81 Wis. 2d 491, 261 N.W.2d 434 (1978).

At least two cases have struck down legislation limiting recoveries in medical malpractice suits. In Wright v. Central Du Page Hosp. Assn., 63 Ill. 2d 313, 347 N.E.2d 736 (1976), the Illinois Supreme Court found such a limitation violative of a state constitutional provision prohibiting "special laws." 63 Ill. 2 d at 329-30, 347 N.E.2d. at 743. Similarly, in Arneson v. Olson, 270 N.W.2d 125 (N.D. 1978) the North Dakota Supreme Court struck down a recovery limitation on state as well as federal equal protection grounds. The court noted that in enacting the statute the legislature had relied on national malpractice insurance rates and concluded that "either the Legislature was misinformed or subsequent events [lower insurance rates] have changed the situation substantially." 270 N.W.2d at 136. As might be expected, these decisions have been criticized. See, e.g., Hines v. Elkhart Gen. Hosp., 465 F. Supp. 421, 428-29 (N.D. Ind. 1979) (Wright and Arneson "severely criticized and rejected by courts and commentators," referring to jury trial denial claim), affd., 603 F.2d 646 (1979); Prendergrast v. Nelson, 199 Neb. 97, 107, 256 N.W.2d 657, 665 (1977) (Wright not persuasive). Cf. Redish, Legislative Response to the the Medical Malpractice Insurance Crisis: Constitutional Implications, 55 TEXAs L. REv. 759, 782 (1977) (concluding that courts should not frustrate "social legislation developed by representative legislative bodies . . . by judicial speculation").

12. Bickel, The Supreme Court 1960 Term - Foreward: The Passive Virtues, 75 Harv. L. REV. 40 (1961).

13. 1 K. Davis, Administrative LaW Treatise \& 3.1, at 149-50 (1978) ("Since 1935 the nondelegation doctrine has had no reality in the holdings, although remnants of the doctrine persist in judicial verbiage."); see also T. Low, THE END OF LIBERALISM 92-126 (2d ed. 1979); Bensel, Creating the Statutory State: The Implications of a Rule of Law Standard in American Politics, 74 AMER. POL. SCI. REv. 734 (1980) (suggesting what criteria statutes should conform to in order to satisfy "rule of law" standard); Posner, Economics, Politics, and the Reading of Statutes and the Constitution, 49 U. CHI. L.'REv. 263, 288-90 (1982) (advancing an economic 
proaches he canvasses - void for vagueness, a modern day version of cessante ratione legis, cessat et ipsa lex, and desuetude - could not, if taken together and applied creatively, provide a reasonably effective means of addressing obsolescence. ${ }^{14}$ But he rejects all of these possibilities as either overinclusive or underinclusive, or both, or because they fail to focus on what he views as the critical question: whether an anachronistic statute enjoys current support. Vagueness fails because "[m]any anachronistic statutes are clear as can be" (p. 25), desuetude fails because "[m]any old laws that are out of phase and would not be reenacted are still enforced" (p. 21), and the cessante ratione legis rationale would produce invalidation where new rationales would support the law, and might not produce invalidation where, although the old rationale is "plausibl[e]," it is "out of tune with the total law" (p. 23).

The third and final judicial response that Calabresi rejects is the one most readers might suspect is the most efficacious - statutory interpretation. Briefly, he argues that the range of discretion courts can properly exercise in interpreting a statute prevents them from addressing the obsolescence problem squarely: "The limits of honest interpretation are too constricting, whereas the scope and dangers of unlimited interpretation are too broad" (p. 38). Surely this is correct, at least in those cases where a statute simply and unequivocally commands the courts to apply a particular decision rule - e.g., contributory negligence bars recovery - in specific cases. How many statutes fall into this category is another question. Many statutes - perhaps most statutes - are vague enough to allow courts to keep them current without doing damage to the "core of honest interpretation." In the hands of inventive judges, the reach of interpretation would seem broad indeed. ${ }^{15}$ Conversely, the "dangers of unlimited interpretation" are not themselves unlimited; the same limit that Calabresi argues would check an inappropriate use of his doctrine - legislative reversal of judicial decisions - certainly checks "unlimited interpretation."

Calabresi then explores whether the "New Deal Response" - delega-

justification for delegation of legislative power to administrative agencies). But see Industrial Union Dept. v. American Petroleum Inst., 448 U.S. 607, 673 (1981) (Rehnquist, J., concurring in the judgment on nondelegation grounds).

14. See, eg., Petteys v. Butler, 367 F.2d 528, 536 (8th Cir. 1966) (holding a particular transaction to be outside the definition of "purchase" under $\$ 16(\mathrm{~b})$ of the Securities Act. "When the reason of the law ceases, the law itself ceases [to operate]... . Since the purposes of the Act are stated clearly and appear side-by-side with the literal demands [it is appropriate] to determine on an ad hoc basis whether the purposes of the Act are in any way being served by an application of the literal provisions."), cert. denied, 385 U.S. 1006 (1967).

15. An obvious example is the River and Harbors Act of 1899, 30 Stat. 1151, 33 U.S.C. $\S \S 403,407,411$ (1976). See W. RodGers, ENVIRONMENTAL LAW \& 4.5, at 387 (1977) (Water pollution regulation is "influenced importantly by the humble specifics of a nineteenth-century statute that is almost an insult to the sophisticated wastes of modern technology. It has served nonetheless as a remarkably flexible deterrent to water pollution of every conceivable manner, shape and form."). The Sherman Act is another example of a statute that has retained its vitality despite its age. For an example of a pinched and hidebound approach to statutory interpretation in a case involving a state counterpart of the Sherman Act, see State v. Mobil Oil Corp., 38 N.Y.2d 460, 464, 344 N.E.2d 357, 381 N.Y.S.2d 426, 428 (1976) (rejecting the argument that the term "arrangement" covers a price discrimination practice in the absence of "a reciprocal relationship of commitment between two or more legal or economic entities," despite indications that state statute's scope was intended to be broader than the Sherman Act). 
tion of broad policy mandates to administrative agencies - is likely to offer a solution. He concludes that, as agents of change, administrative agencies have been "a dismal disappointment" (p. 45). Although he is quick to caution the reader at several points that the conventional wisdom about how and why bureaucrats "satisfice" 16 is simplistic and sometimes misleading, most of this section does little more than summarize that wisdom. But there is a shift in emphasis here. Calabresi's assessment of the possibility that agencies can tackle the problem of obsolescence necessarily entails a comparison: If courts suffer from the same problems that plague agencies they are unlikely to be any better at solving the problem. His definition of an obsolete statute - a statute that does not "fit" the legal topography and lacks current legislative support - guides the comparison.

He concludes that, on balance, agencies are less likely than courts to be able to discern lack of "fit" or gauge current support. Agencies cannot spot lack of fit because they are either too closely involved with their own statute or insufficiently familiar with the rest of the legal landscape. Somewhat paradoxically, it is precisely because they are politically accountable that their reading of majority wishes is, in Calabresi's view, suspect: "Political accountability leads almost inevitably to an overblown faith in one's capacity to know what the majority wants, and hence to a tendency to emphasize this aspect of lawmaking to the detriment of consistency" (p. 53). Courts, on the other hand, are trained to interpret the legal topography and are, by virtue of their relative insulation from the play of day-to-day politics, better able to follow it: "Strange to say, an elected court is more independent, less subject to the force and whim of particular legislators and executives, than even regulators on long-term appointments" (p. 53). At this point, readers will probably feel that the case for courts and against agencies is made out a little unfairly; it seems that courts are given the benefit of every doubt, while many recent developments that promise to promote agency accountability and efficiency are treated, if at all, only in footnotes. ${ }^{17}$

Calabresi then dismisses in rapid succession sunset laws, law revision commissions, and efforts to make lawmaking more representative through either reform of the legislative process itself or more frequent resort to direct lawmaking. Sunset laws are too mechanical and are likely to degenerate into a mere formality; law revision commissions steer clear of controversial issues; structural reform of the legislative process "would reallocate power and make law revision too easy" (p. 71); the initiative and referendum processes are dismissed as posing "dangers . . . [that] form a commonplace part of the literature" (p. 70).

His confidence in dismissing all of these alternatives as inadequate is striking. Although sunset laws are a relatively recent phenomenon, Cala-

16. See Simon, A Behavioral Model of Rational Choice, 69 Q.J. Econ. 99 (1955).

17. See, e.g., Cutler \& Johnson, Regulation and the Political Process, 84 YALE L.J. 1395 (1975) (arguing that presidential control over independent agencies should be increased, subject to a one-house congressional veto). Presidential control over the rulemaking of executive agencies has been effected by Executive Order 12,291, 3 C.F.R. 127 (1982), but independent agencies remain free from such oversight. The constitutionality of a one-house veto is currently before the Supreme Court in Immigration \& Naturalization Serv. v. Chadha, 51 U.S.L.W. 3453 (U.S. Dec. 14, 1982) (reargument) (No. 80-1832). 
bresi concludes that sunsetting will "defeat itself" (p. 61).18 He relies on dated support for his assertion that law revision commissions avoid making controversial recommendations, and ignores other evidence that tends to contradict this assertion (pp. 62-63). ${ }^{19}$ Structural reform of the legislative process is dismissed as out of keeping with an ideal construct of the legislative/judicial balance despite the wide variance in state legislative structures and despite evidence indicating that states are pursuing reform efforts to streamline the legislative process. ${ }^{20}$ Finally, the resurgence of direct legisla-

18. Certainly the state legislatures are not as pessimistic about the sunset approach as Calabresi - some forty-four states have enacted sunset legislation of one sort or another. See Council of State Governments, 1982-83 Book of THE STates 228-31 (Table \#27, Summary of Sunset Legislation). For an example of a particularly ambitious sunset statute, see FLA. STAT. ANN. $§ 11.61$ (West Supp. 1982, at 105-12) (listing over 3,000 statutory provisions that are to be phased out absent legislative action between 1982 and 1991). The Florida statute avoids one of the primary faults Calabresi finds with sunset statutes - the possibility of a statute being "bottled up" in committee - by providing that "each appropriate subcommittee shall begin a review . . . 15 months prior to the date set for repeal . . and shall make a recommendation ... for continuation, modification or repeal of the program or function . . ." Fla. Stat. ANN. \$11.61(3) (West Supp. 1982). The most dramatic effect of the Florida legislation to date has been the deregulation of the trucking industry, see Deffenbaugh \& Hayman, Motor Carrier Deregulation in Florida: Before, During and After, 8 FLA. ST. L. REv. 681 (1980). Trucking interests challenged the statute's operation on various constitutional grounds, but the deregulation was upheld. See Alterman Transp. Lines, Inc. v. State, 405 So. 2d 456 (Fla. Dist. Ct. App. 1981) (upholding repeal of motor carrier regulation pursuant to sunset act against constitutional challenges based on contract clause, fair notice and court access grounds).

19. See, e.g., Report of the Law Revision Commission for 1980, 1980 N.Y. Laws 1597, 1613 (McKinney) (urging elimination of "impermissible sex distinctions with respect to the obligations of parents to support their children and husbands and wives to support each other"); Report of the Law Revision Commission for 1981, 1981 N.Y. Laws 2235, 2336 (McKinney) (urging amendment or repeal of thirty-one state statutes "which discriminate, in a constitutionally impermissible manner, against aliens who have been lawfully admitted for permanent residence in the U.S. under federal immigration laws"). See also Abrams, New York's Legislature Tries Harder, 46 STATE GovT. 256, 258 (1973) (establishment of Task Force on Critical Problems aimed at "focus[ing] on key issue areas that need long-range assault, such as reducing welfare costs or providing universal health insurance. The evolution of this office will be watched carefully by legislators around the country for its implications as an "inspector general" type function in the ... [1]egislature, or it may evolve into a new type of program development agency.").

20. Although the committee system is well established in state legislatures, recent research suggests that its importance varies significantly from state to state. See Francies \& Riddlesperger, U.S. State Legislative Committees: Structure, Procedural Efficiency, and Party Control, 7 LEgis. STud. Q. 453 (1982) (Table 3, "Committee Centrality Scores by State and Chamber" indicating "rather sharp differences in committee importance among the 99 legislative chambers"). Few states use subcommittees extensively, see M. Jewell \& S. PATterson, The LEGISLATIVE Process IN THE UNITEd STATES 203 (1977), and this is one area where it is hoped reform efforts might bear fruit. For a study that concludes that a change in committee structure will not necessarily lead to greater legislative efficiency - efficiency being measured by the congruence between committee recommendations and full floor votes - see Hamm \& Montcrief, Effects of Structural Change In Legislative Committee Systems on their Performance in U.S. States, 7 LEGIS STUD. Q. 383 (1982). Calabresi, along with many other observers, views the committee system as largely responsible for the dysfunction of the legislative process, see generally Brenner, Congressional Reform: Analyzing the Analysts, 14 HARv. J. ON LEGIS. $651,664-70$ (1977), and so he gives little attention to structural and procedural reforms aimed at dovetailing the committee system with the larger legislative process. Legislators, on the other hand, understand that the committee system is inevitable, given the volume and complexity of legislation, and accordingly view the proper purpose of reform as strengthening the 
tion spanning an issue spectrum ranging from nuclear disarmament to denturism is barely considered. ${ }^{21}$ And Calabresi never explains why the legislative reconsiderations his doctrine would induce would not also be bottled up in committee, receive greater attention than issues considered by law revision commissions or "blue-ribbon" committees that work closely with the legislature, ${ }^{22}$ or simply fall victim to the same structural obstacles all legislation confronts.

All of these objections, of course, are little more than nit-picking. Calabresi's thesis obviously does not depend on the utter absence of workable judicial, administrative or legislative responses to the problem of obsolescence. Nor is it necessary for him to prove that his doctrine is the most attractive approach. It is enough if the doctrine merely contributes to a solution. Why then does he categorically reject all of these alternatives as insufficient? One suspects that Calabresi's approach is rhetorically onesided for two reasons. First, he is attempting to convince readers - many of whom are likely to be skeptical ${ }^{23}$ - that statutory obsolescence is a problem. Second, Calabresi states at several points in the book that his intention is to offer only a tentative formulation of the doctrine, a formulation he hopes will prompt reaction and discussion. In devoting the first half of the book to rejecting what he perceives to be unwitting or misguided attempts to keep statutory law current, he has elevated the level of discussion by setting the standards against which his proposal will be evaluated. But how does his doctrine work?

committee system to facilitate the flow of legislation, see Montcrief \& Jewell, Legislator's Perceptions of Reform in Three States, 8 AMER. PoL. Q. 106, 116-18 (1980).

21. See generally Referendums: A CoMparative Study of Practice and Theory (D. Butler \& A. Raney eds. 1978). Calabresi should have spent more time addressing the direct legislation process as an alternative, if only because the small show of support necessary to lodge a question on the ballot - in California, for example, well under $5 \%$ of the voting public can force reconsideration of a statute, id. at 92 - seems to cast doubt on his assumptions concerning "majority sentiment" and failure of the legislative process. There are, of course, analysts who suggest that direct legislation suffers from the same problems that beset the conventional legislative process, see, e.g., Mastro, Costlow \& Sanchez, Taking the Initiative: Cor. porate Control of the Referendum Process Through Media Spending and What to do About it, 32 FED. COM. L.J. 315, 319-20 (1980), but the returns so far seem to indicate that corporate and other "special interests" groups have been unsuccessful in their attempts to use the initiative or referendum to "buy" legislation. Compare Calabresi's offhanded dismissal of direct legislation with the conclusions of those who have studied the process more thoroughly. See, e.g., Bone \& Benedict, Perspectives on Direct Legislation: Washington State's Experience 1914-1973, 28 W. PoL. Q. 330, 349 (1975) (concluding that direct legislation has been successful as an alternative to the legislative political process); Price, The Initiative: $A$ Comparative State Analy. sis and Reassessment of a Western Phenomenon, 28 W. PoL. Q. 243, 261-62 (1975) ("The initiative does provide a last resort to the public to bypass a recalcitrant legislature and/or governor. ... Clearly, initiatives do allow for decisive decisions on particularly sensitive, hard to resolve, issues.").

22. See, e.g., Ratchford, Red-Letter Achievements from Blue Ribbon Panels, 51 STATE GovT. 59, 59 (1979) (lamenting the fact that valuable reports of panels assigned to study various problems meriting legislative attention often "gather dust and the scorecard is poor for having recommendations translated into law and meaningful programs" and documenting the successful efforts of a blue-ribbon panel in Connecticut charged with studying the nursing home industry).

23. See Coffin, supra note 3 , at 837. 
II

Calabresi defines an obsolete statute as one which (1) no longer fits the legal topography and (2) lacks current legislative support. Courts using his doctrine would be on the lookout for statutes that "not only could not be reenacted but also do not fit, are in some sense inconsistent with, our whole legal landscape" (p. 2). The centerpiece of Calabresi's doctrine, then, is the notion of a "legal fabric, topography, or landscape" (p. 51).

Ultimately, Calabresi believes it is appropriate to grant courts the power to call old statutes due because courts are better than other political actors at the "rational application of legal principles" (p. 96). ${ }^{24}$ It is therefore reasonable to ask whether the central principle of his doctrine, the notion of a legal topography, is capable of consistent, rational application. If courts are not capable of applying the concept consistently, the essential justification for exercising the power Calabresi would grant them is undercut. This is not merely an analytic nicety. As long as courts can agree on the principles they apply, decisions in individual cases that are inconsistent with those principles or simply wrongly decided work only limited damage. But the danger of inconsistent application of a concept that would "induce" or "force" a legislative reconsideration is much greater, both because of the number of individuals affected and the likelihood that legislators will re-

24. Calabresi's perspective on the legitimacy question is functional. He states that

the skills the court would be called on to use . . . remain judicial skills, and hence the legitimacy of their exercise remains the same as the common law. The power is legitimate because it results from the use of special judicial skills - analysis of the legal topography - and because employment of these skills tends, albeit indirectly and imprecisely, to adjust the law to deep majoritarian wishes.

P. 108. Compressed a little, Calabresi's argument is that courts can legitimately do whatever it is they are capable of doing as courts, because they are courts. Whether the arguments made for judicial intervention where failure of the legislative process threatens individual rights or the validity of the process itself from a participational perspective, see generally J. ELY, DEMOCRACY AND DISTRUST (1980), possess the same force when applied to mundane, workaday statutes is another question. Although Calabresi argues at length that adoption of his doctrine would not require courts to perform functions different from those performed at common law, his scheme surely represents a radical departure from existing practice. His reliance on a purely functional as opposed to a normative justification for the doctrine leaves him open, of course, to criticism from a functional as well as a normative perspective. Readers who believe that the judiciary should be limited to interstitial lawmaking because it is simply not "representative" will probably reject the doctrine on normative grounds, without regard to snazzy functional arguments. For them, Calabresi's legitimacy arguments will fail because they never progress beyond arguments of competency to address questions of political theory. See generally Dahrendorf, Effectiveness and Legitimacy: On the Governability of Democracies, 51 PoL. Q. 393, 396 (1980) ("Effectiveness is a technical concept. It simply means that governments have to be able to do things which they claim they can do, as well as those which they are expected to do; they have to work. Legitimacy, on the other hand, is a moral concept. . . . This takes us straight into the confusions of moral philosophy, of course."); Grafstein, The Failure of Weber's Conception of Legitimacy . . . Its Causes and Implications, 43 J. PoL. 456 (1981). Readers who equate competency with legitimacy will still have to evaluate the doctrine in terms of the plausibility of the claims Calabresi makes about the judiciary's ability to follow the "topography" and plumb majority sentiment.

Calabresi, of course, must reject the traditional wisdom that statutes are to be revered because they have been left undisturbed (p. 102). See J. Rousseau, THE SocIal ConTract 135 (Penguin Books ed. 1968) ("Why then do ancient laws command so much respect? Precisely because they are ancient. We must believe that it is only the excellence of such laws that has enabled them to last so long; if the sovereign had not continually recognized them as salutary, they would have been revoked a thousand times."). 
spond to "wrong" decisions by attacking the doctrine directly rather than by merely "correcting" courts. ${ }^{25}$

The legal topography would include common-law decisions, statutes, administrative determinations, jury verdicts, enforcement patterns, scholarly criticism - in short, just about everything except the legislator's mail bag. But he offers no more than an enumerative definition of the topography; he lists virtually every conceivable landmark that might be found on an all-encompassing legal landscape ${ }^{26}$ but provides no roadmap or compass to guide courts in their journey. Readers will have to judge for themselves whether Calabresi's topography is comprehensive and coherent enough to guide a judicial decision to induce legislative reconsideration and make that decision appear to a legislature to be a principled one. He anticipates the criticism that, as defined, his topography is "a confused landscape . . . a ragged map" (p. 99). His only response is a demure reminder that "limits as a practical matter remain" (p. 100). ${ }^{27}$ One's willingness to embrace Calabresi's doctrine will probably depend on one's perception of where those limits might lie.

For Calabresi, the topography is both a comparative and a normative reference point. He would use it comparatively, as a sort of template, to gauge how far out of line a statute is with existing legal practice. Thus, workman's compensation laws or wrongful death statutes that limit the amount, or against whom, plaintiffs may recover might be inconsistent with

25. The risk of legislative repudiation of the doctrine is reduced somewhat by limiting the doctrine's use to the highest court of a jurisdiction and by imposing a "comity" limitation. Although Calabresi feels that an explicit delegation from the legislature would be desirable, he believes that this is not necessary. Whether the existence of law revision commissions or standing committees charged with performing the same function courts would perform under Calabresi's doctrine amounts to a negation of the discretion he feels courts have to adopt the doctrine without explicit delegation is nowhere considered. See, e.g., Mich. CoMp. Laws $\S \S 4.311-4.327,4.324$ (1979) [Legislative Council Act] ("The law revision commission shall ... [e]xamine the common law and statutes of the state . . . for the purpose of discovering defects and anachronisms in the law . . . [, and] recommend . . . such changes in the law . . . necessary in order to modify or eliminate antiquated and inequitable rules of law, and to bring the law of this state . . . into harmony with modern conditions.").

26. Narrower, more precise definitions of topography are possible. Both Ronald Dworkin and George Christie have defended modelling the system of precedent as a set of data points; the judge's mission is to find the best fit among them. Both these theorists, however, confine the data points to cases, statutes, and constitutional provisions, the traditional elements of positive law. See generally G. ChrISTIE, LAW, NORMS AND AUTHORITY (1982); note 31 infra.

27. The footnote supporting this statment refers to "outside boundaries" that prevent judges from "decid[ing] cases as they would were they legislators or even disinterested guardians" (p. 256 n.37), without suggesting the limits of these boundaries. Ultimately, one must take comfort in the consolation that "[o]ne judge's views would win out only if enough other judges either found that they conformed to the legal landscape or, finding no adequate guidelines in the landscape, still shared the judge's guess of what the majority wanted or of what was right for the country." P. 100. The latter factor sounds a lot like what legislators are supposed to do. The first factor - consistency with the legal landscape - reformulates at a fairly high level of abstraction that characteristic of adjudication upon which legitimacy is generally premised reasoned elaboration of a result from generally agreed upon premises. See R. PoUND, AN INTROdUction to THE Philosophy OF LAW 116 (1922); Friedrich, Authority, Reason, and Discretion, in Nomos I: AuThORITY 28 (C. Friedrich ed. 1958). Whether the "topography" is clear and stable enough to function as such a premise is questionable; it seems more likely that each obsolescence determination will be largely sui generis, particularly in cases where a statute has preempted large portions of common law. 
tort law developments allowing recovery without regard to fault or the plaintiff's relationship to the defendant. Calabresi believes that using the topography comparatively is justified because the topgraphy also represents a normative datum or "starting" point: He argues that the topography fairly accurately "reflect[s] the underlying desires of a society as these have evolved" (p. 97).

Those who believe that judges inevitably indulge their own values regardless of the ordering principles they purport to rely on will probably dismiss the concept of a topography as an atavism of the formalist's theory of jurisprudence. ${ }^{28}$ Even those who concede that judges cannot shed their values when they don their robes, but nevertheless welcome the countermajoritarian influence of judges as "disinterested generalists"29 might question whether the topography can, as a practical matter, be applied. ${ }^{30}$ It bristles with so many varied elements that it is difficult to be optimistic about the possibility of systematically defining its contours. Assuming that one is prepared to accept that there is a topography - an "out there" that can be discussed meaningfully - there is little in Calabresi's description of it to indicate any ordering principles. ${ }^{31}$ Thus, should the research suggesting that jury selection procedures result in unrepresentative

28. See Unger, The Critical Legal Studies Movement, 96 Harv. L. Rev. 561 (1982). According to Unger, formalism supposes an

immanent moral rationality whose message [can] be articulated by a single cohesive theory. This daring and implausible sanctification of the actual is in fact undertaken by the dominant legal theories and tacitly presupposed by the unreflective common sense of orthodox lawyers. Most often, the sanctification takes the form of treating the legal order as a repository of intelligible purposes, policies, and principles, in abrupt contrast to the standard disenchanted view of legislative policies.

Unger, supra, at 571 (emphasis added).

29. Wellington, The Nature of Judicial Review, 61 YALE L.J. 486, 493 (1982). See M. Perry, The Constitution, The Courts, AND Human Rights 102 (1982) (arguing that in cases involving individual rights "the politically insulated federal judiciary is more likely, when the human rights issue is a deeply controversial one, to move us in the direction of a right answer . . . than is the political process left to its own devices").

30. This is not to say, however, that there is no support for the notion that judges can accurately apprehend the legal topography. Dworkin's theory of judicial mistakes turns on just such perceptions of the legal landscape; a precedent should be overruled, he argues, whenever the best justification for the entire legal system is stronger after overruling a decision than it would otherwise be. Dworkin applies this reasoning in two forms; a case or statute now simply inconsistent with the legal topography, but not fundamentally unfair, retains its specific authority but loses its gravitational force. That is, the principles of the old decision will not be extended in the decision of new cases, but situations precisely within the facts of the prior holding will still be resolved accordingly. Where fundamental fairness is at stake, Dworkin deems the inherent costs of overruling justified by eliminating the precedent complained of. See R. Dworkin, Taking Rights Seriously 110-23 (1978).

Interestingly, Dworkin does not go so far as Calabresi in repudiating statutes that are inconsistent with the legal topography. Hercules" 'theory of legislative supremacy . . . will insure that any statutes he treats as mistakes will lose their gravitational force but not their specific authority." R. DWORKIN, supra at 122 . But the comprehension of the legal topography involved in evaluating cases and statutes is of course the same. Those persuaded by Dworkin's account of precedent should not object to Calabresi's reliance on judicial perceptions of the legal topography.

31. Absent such principles, the value of Calabresi's contribution seems problematic: The topography is all content and no form, and therefore largely useless no matter how accurately it might be mapped. See M. Polanyi, Personal KNowledge 139-40 (1962) (striving for "universal knowledge" of a world composed of "exactly determined particulars . . . is mis- 
juries $^{32}$ temper a judge's evaluation of their place on the topography? Should the prominence of a trend of common law decisionmaking in tort cases depend on whether a judge accepts Horwitz's, Posner's, or Schwartz's interpretation of the trend? ${ }^{33}$ Are the determinations of an independent agency to be given greater weight than those of, say, the NLRB, on the theory that they are less subject to factious influence? Or vice versa?

Calabresi of course recognizes that these difficulties are, so to speak, part of the territory. He concedes that courts will sometimes err, and is careful to emphasize throughout the book that a judicial determination of obsolescence is "conditional" because it is subject to legislative reversal. He notes that in applying the topography courts will occasionally "ignore it .. . follow the election returns or their own values," but concludes that "these values, and their guesses on majority wishes, are not all that bad" ( $p$. 101). Legislators, of course, feel the same way about their "values" and "guesses on majority wishes," and this suggests that the real question is whether legislatures are likely to be persuaded that courts, in employing the doctrine, would be doing something more than substituting their own values and assumptions for those that animated an old statute. The efficacy of the various "second look" doctrines Bickel urged probably derives from the context of their use - in cases that might be dubbed subconstitutional. But Calabresi's doctrine is not necessarily limited to statutes that, as he puts it, skate close to the constitutional line. Whether legislatures are likely to "view [an] issue soberly" (p. 26) on the basis of a finding that a statute does not fit a topography that only a court can chart, or that different courts chart differently, is the critical question. Legislatures that balk at honoring decisions that turn on constitutional "penumbras" are likely to be equally suspicious of such "topographical" holdings. ${ }^{34}$

Suppose, however, that Calabresi's faith in the ability of judges to discern and follow the topography in a reasonably consistent fashion is byand-large well-placed. The examples he draws on - a guest statute floundering in the wake of common-law developments, a statutory comparative negligence gloss that the common law bypassed, and others - suggest that in many cases the topography will be manageable because most of it will be irrelevant. But this is only half the battle: Even if a statute snags the

taken, since it substitutes for the subjects in which we are interested a set of data which tell us nothing that we want to know").

32. See, e.g., Winick, Prosecutorial Peremptory Challenge Practices in Capital Cases: An Empirical Study and a Constitutional Analysis, 81 MiCH. L. REV. 1 (1982).

33. See M. Horwitz, The Transformation of AMERICAN LaW 67-108 (1977) (tort doctrine effected subsidy to developing industries); Posner, $A$ Theory of Negligence, $1 \mathrm{~J}$. LeaAL STUD. 29 (1972) (tort doctrine accords with notions of economic efficiency); Schwartz, Tort Law and the Economy in Nineteenth-Century America: a Reinterpretation, 90 Y ALE L.J. 1717, 1774 (1981) (concluding that tort doctrine evinced concern for victims).

34. Consider, for example, the proposed amendment to the Massachusetts Constitution which would extend the legislature's authority over abortion laws to the "outer limits" of constitutional doctrine:

Nothing in this Constitution shall prevent the General Court from regulating or prohibiting abortion unless prohibited by the United States Constitution, nor shall anything in this Constitution require public or private funding of abortion, or the provision of services or facilities therefor, beyond that required by the United States Constitution.

Massachusetts Senate Journal, Jan. 3, 1983, at 1375 (on file with the Michigan Law Review). 
legal fabric, a judge must still determine whether the statute would be reenacted, whether it enjoys current legislative support.

Calabresi admits that "if the object were . . . to pick a body that could discern the current majority's wishes . . . we almost surely would not pick judges for the task" (p. 100), ${ }^{35}$ but he argues that in deciding whether a statute is "no longer desired by a current majority," courts would be exercising a judgmental function analogous to the one they exercised at common law (p. 112). He observes that "[i]ncreasingly . . . it seems that courts are relying on their sense of what the majority wants to define the outward boundaries of their lawmaking," and concludes that as long as: courts first "look to the landscape" to ascertain lack of fit, because this "reflect[s] a deeper popular will," the "guess, increasingly made at common law, as to majoritarian wishes will inevitably be made" (p. 113). Thus Calabresi completes the circle, tying the legitimacy of deciding when a statute lacks current support to the topography as an alembic for deep majoritarian wishes. Bringing statutes into conformity with the topography therefore partakes of the same legitimacy as common-law decisionmaking.

Unfortunately, the circle has been completed at a level of generality and abstraction that is miles above the nitty gritty of legislative politics. One therefore wonders if the "majority support" component of the obsolescence inquiry can really assist courts in deciding whether there is current legislative support for a statute, or whether, instead, courts would be operating as reversible Councils of Revision. In this connection, some readers might question in just what sense Calabresi is arguing that courts are capable of discerning majority wishes. Early in the book, in a footnote, he promises that he will use "majoritarian" in a "rather special sense"; he defines "majoritarian preference" to mean "whatever a current representative legislature would decide on a question to which it gives its full consideration" (p. 186 n.13). But the passages quoted above, with one exception, all seem to stand for the proposition that courts, when confronted with what are essentially policy choices, will often decide a question with reference to what they believe to be prevailing public sentiment, on the theory that this is likely to maximize utility or, at the least, minimize the antidemocratic consequences of judicial review. There is a world of difference between this inquiry and one which asks whether a legislature would reenact a particular statute unchanged or how the statute might be modified. The latter inquiry

35. Happily, Calabresi does not harangue the reader with an extended addition to the "courts are more democratic than . .." debate. His doctrine straddles the uncertain line between article I and article III and his approach is accordingly fully comparative. The eloquence with which he frames the inquiry makes it dangerous not to quote him at length:

Not so readily resolved is the question of whether skill at discerning current popular support, capacity to anyalyze and follow the legal topography, or endowment with a trustworthy sense of values is most important in the updating of timeworn laws.

The decision must depend, in part, on how common are the situations that are well handled by each approach. It must also depend on how poorly each approach would deal with those situations it is not best suited to handle. . . . Ideally, the task of deciding when the burden of inertia should be shifted would be placed on a body that has all three qualities.

Such a body is not available. . . . Courts do, however, have an advantage over alternative institutions. They are not clearly unsuited to the tasks at which they are not particularly good.

Pp. 110-11. 
would involve courts in analyzing committee politics, interest group positions, whether there have been any efforts to change the statute in the past and why those efforts have failed, etc., - in short, a review of the complexities of the legislative process, preferably from the perspective of those interests associated with the specific issues the statute reflects. ${ }^{36}$

The potential for rather wide divergence between a court's perception of majority sentiments and the majoritarian forces actually operative in the legislative arena suggests that, in all but the simplest of cases, the former is unlikely to be a useful surrogate for the latter. The majority sentiment prong of the obsolescence test appears to be mere window dressing, designed to appease those who would reject the proposition that courts should be able to force legislative reconsideration of a statute whenever it does not fit the topography. But how can the doctrine amount to anything more than this if the courts rely on a notion of majority sentiment that ignores the vagaries and distortions of the legislative process itself? Calabresi's answer to this is that a court's perception of majority sentiment is adequate to serve as a starting point. From this starting point, the argument goes, legislative reconsideration can proceed and the reconsidered statute will at least be the product of a more recent majoritarian decisionmaking process, and it might even fit the legal topography better.

The first point is true, but trivial. It is true because whenever a legislature reconsiders a statute the outcome is by hypothesis a "majoritarian"

36. Clearly, courts are not capable of undertaking the "majoritarian" analysis necessary to decide whether a particular legislative committee or legislature would countenance a statute's current lack of "fit" with the legal topography. They are not privy to the information needed for such an analysis, and the intricacy and uncertainty of the legislative process would reduce such an effort to a guessing game. Accepting Calabresi's premise that judicial review of the common-law variety is legitimate because courts are in some way restrained by majority wishes does not lead one smoothly to the conclusion that courts are also capable of deciding when a statute is no longer desired by a legislative majority; this transmutes what is most often offered as an apology for judicial review into a positive virtue. See, e.g., L. HAND, THE BILL OF Rights 15 (1958); Cooper, Mr. Justice Hugo L. Black: Footnotes to a Great Case, 24 ALA. L. REV. 1, 5 (1971).

If one adheres to the view that there is often no real majority sentiment on most issues, but only an ongoing tussle between constituencies that is occasionally settled by legislation, the proposition that courts can discern majority sentiments better than legislators on such issues seems weak indeed. The judicial assessment of majority wishes therefore seems to add very little one way or the other to the doctrine, at least in cases involving statutes that are more complicated than the straightforward, single-issue affairs that Calabresi uses as his primary examples. Guest statutes, contributory negligence statutes and statutes that limit wrongful death recoveries present attractive cases for arguing that courts can assess majority sentiment because the issues are simple and preferences can be easily hypothesized since they divide neatly into obvious categories. It is difficult to believe that, for more complicated statutes, the majority sentiment prong of the obsolescence inquiry can lead to determinate answers. If a statute involves several issues with respect to which individual rank order preferences among individuals may vary, or with respect to which the rank order preference of a single individual may vary, depending on what preferences will be honored, it is essentially meaningless to speak of a single, identifiable "majority preference." See generally K. ARROW, SOCIAL CHOICE ANd Individual Values (2d ed. 1963); A. Mackay, Arrow's Theorem, The Paradox of Social ChOICE (1980). And of course courts cannot take account of the various interests extrinsic to any single piece of legislation that inevitably engender compromise and trade-off in the actual legislative process. There may be some Burkean merit to considering single statutes in a rarified manner, but it is difficult to conclude that this comports with traditional modes of assessing majority preference. 
one. It is trivial because it tells us nothing about whether a court was "correct" in remanding the statute. Whenever a legislature does anything more than pass a pro forma resolution indicating that a statute stands, warts and all, the new statute will almost always differ from the old one, if only because the legislative environment - the coalitions that form around the legislation, the logrolling, the vote trading, etc., - shifts from one session to the next. Thus, if the remand is taken seriously, i.e., if the issue is tossed back into the legislative hopper, the law probably will not resurface in precisely the same form. If this is the criterion for deciding whether the guess as to majority sentiments was correct, courts will rarely be demonstrably wrong. Why a new pluralist mishmash is better than an old one, however, is unclear, unless we have some reason to suspect that in addition to being newer the revised statute will have something else to offer. That "something else," of course, must be derived from the reasons that caused a court to send the statute back in the first place if Calabresi's doctrine is to have any internal validity.

The "something else" a new statute should have, if Calabresi's doctrine is to be distinguished from the approaches he rejects, is consistency with the topography. It is not enough to say that the doctrine is desirable because it causes legislatures to consider issues that have not been considered for some time. This is just what sunsetting does, and Calabresi rejects sunsetting precisely because it ties reconsideration to a calendar. And it doesn't add much to the doctrine to argue that it will tend to select out those statutes that are most in need of reconsideration from a "majoritarian sentiment" perspective if, as is likely to be the case in practice, a court's perception of majority sentiment is blind to the far narrower majoritarian forces that will inform the process of reconsideration. Newer is not necessarily better; ${ }^{37}$ a decision that an abstract majority would prefer a different statute is a rather poor predicate for sending a statute back into a legislative cauldron that might yield up any number of different brews, some savory, some not. And even if courts were able to plumb majority sentiment better than legislatures on issues that most people have no opinion on one way or the other, the deficiencies of the judicial system as a representational arena ${ }^{38}$ surely caution against granting courts the power to displace the legislative agenda unless some very real gains in terms of consistency with the topography are

37. And the old law may be better than no law at all, depending on who is left holding the power. See Galanter, Why the "Haves" Come Out Ahead: Speculations on the Limits of Legal Change, 9 LAW \& Socy. Rev. 95, 139 (1974) (citing study concluding that liberalization of censorship law "did not make censorship boards more circumspect; instead, many closed down and the old game between censorship boards and distributors was replaced by a new and rougher game between exhibitors and local government-private group coalitions").

38. That courts attract interest groups which are incapable of achieving their objectives through the political process is well known. See, e.g., M. Shapiro, Freedom of SpeEch: The SUPREME COURT AND Judicial Review 34-37 (1966). The death penalty cases illustrate that devoted advocates are as adept at pressing their cause as lobbyists, see Meltsner, Litigating Against the Death Penalty: The Strategy Behind Furman, 82 YALE L.J. 1111, 1112 (1973), and courts adopting Calabresi's doctrine should expect interests that have lost in the legislature to turn to litigation. At a minimum, the doctrines governing standing and intervention would have to be reappraised in light of the obvious need for a balanced perspective on the question of a statute's obsolescence. 
likely to result. How likely is the application of the doctrine to produce such a result?

\section{III}

The short answer to that question is: it depends. It depends on how the doctrine is applied. In its simplest form, the doctrine would amount to no more than remanding a statute - i.e., sending it back for legislative reconsideration. In other cases, if the courts knew what form a new rule should take - what would be consistent with the legal topography - they would merely begin to update the statute themselves. Or courts could nullify a law, or some portion thereof, if they were sure that the law was important enough that the legislature would reconsider it promptly. ${ }^{39}$ They could borrow statutes from other jurisdictions, if they thought this was appropriate, and they could give all of this retroactive or prospective effect, depending on what they thought was most likely to elicit legislative response. And "[p]erhaps most important, they can do none of these things, but threaten to do any or all of them, if a legislature or administrative agency does not act quickly. They can shape that legislative or administrative action by announcing, or by failing to announce, what they will do in the absence of such action" (p. 148) (emphasis in original).

This is dialogue with a vengeance. The aim is "to ask, cajole, or force ... the legislature . . . to define the new rule or reaffirm the old" (p. 166). If there are "asymmetries in inertia," courts can properly place the "burden of inertia" on the side that can more easily obtain majoritarian consideration of the statute (p. 126); if a recent statute was the "result of inadvertence, overreaction to a particular set of events, or a legislative response to a temporary majority at war with more persistent social views," courts can send it back for reconsideration; if a statute presents "constitutional, paraconstitutional, or deep structural doubts" (p. 135) and courts are themselves unwilling to invalidate the statute on constitutional grounds, they can question whether it might have been "enacted hastily and without the full consideration that would suggest more than temporary majoritarian support" (p. 136). If all of this suggests that courts would be doing more than humbly submitting statutes for reconsideration - a vote of confidence if you will - the examples Calabresi uses will do little to dispel any doubt that he, too, has an agenda. Thus we are informed that "correct use of the doctrine may do away with [obsolete] statutes that are themselves a major cause of court congestion" (p. 143) by eliminating, for example, "outworn compensation laws" that have resulted in the "expensive and court-burdening end run represented by product liability suits" (p. 143). And "crisis laws" such as "fair trade" legislation, "emergency rent controls," and "emergency malpractice laws that place restrictions on recoveries alien to the rest of tort law" which do not find support in the topography are de-

39. The somewhat lax congressional response to the Supreme Court's decision in Northern Pipeline Constr. Co. v. Marathon Pipe Line Co., 102 S. Ct. 2858 (1982), may leave readers unsure of when legislation is so "important" that swift reconsideration is certain. See 41 Cong. Q. Weekly Rep. 79 (Jan. 8, 1983). See also F. Coffin, The Ways of a Judge 176 (1981) (noting wistfully that judicial suggestions for legislative reform are almost always ignored). 
scribed as the "very statutes that most justify the use of the doctrine here described" (p. 133).

Not surprisingly, Calabresi is most comfortable with statutory examples he is familiar with, and those with respect to which he has definite opinions. The reader is left to guess what the topography might dictate in other areas of the law - particularly areas like property and criminal law - that are stubbornly state-specific despite centuries of debate over what ends these laws should serve and how those ends might best be effected. No matter; other scholars can perform the cartography necessary to map these areas. Everyone has an agenda. If the current literature on constitutional law teaches anything, it is that, and it is hard to shriek "eureka" with much feeling anymore when one peels a doctrine bare to find values at the core. ${ }^{40}$ And it is difficult to fault the value Calabresi is pursuing, despite whatever quibbles one might have with the examples he uses. The value his doctrine hews to, after all, is one that goes to the heart of the legislative process: a deliberation that is both representative and reasoned. ${ }^{41}$

Because Calabresi accepts legislative supremacy, a current legislative decision is a representative one. That much, then, is out of the way, despite the fact that the majority sentiment portion of the obsolescence inquiry is a crude predictor of whether a statute lacks current legislative support and despite the fact that the doctrine is blind to laws that "fit" the topography but might lack current support. "Reasoned" deliberation is another story.

Calabresi's suspicion that the legislative process is anything but reasoned is manifest throughout the book. He questions whether "one [can] truly say that legislatures viewed the [death penalty] issue soberly" in the wake of Furman ${ }^{42}$ (p. 26), and he exhorts courts to use the doctrine to ensure that a "clash [with the topography] is the result of genuine and considered wishes of majoritarian bodies" (p. 136 (emphasis original)), and that constitutionally doubtful laws are enacted "clearly, openly and responsibly." In sum, the courts would assume a role that "encourages the legislatures to act responsibly" (p. 165). But if legislative responsibility means an end result that is either more consistent with the legal topography or the product of a different level of legislative attention, a simple remand of the statute is likely to yield neither.

The reason why simple reconsideration will not necessarily yield greater consistency with the topography hearkens back to the phenomenon of legislative inertia. Calabresi employs legislative inertia as a setpiece in his analysis; in his haste to prescribe a cure, he devotes little time to exploring the cause of the problem his doctrine addresses. He cites another commentator for the proposition that "getting a statute enacted is much easier than get-

40. See Brest, The Fundamental Rights Controversy: The Essential Contradictions of Normative Constitutional Scholarship, 90 YALE L.J. 1063, 1109 (1981) ("most of our writings are not political theory but advocacy scholarship - amicus briefs ultimately designed to persuade the Court to adopt our various notions of the public good").

41. See H. Pitkin, The Concept of Representation 212 (1967) ("Political life is not merely the making of arbitrary choices. . . . It is always a combination of bargaining and compromise where there are irresolute and conflicting commitments, and common deliberation about public policy, to which facts and rational arguments are relevant.").

42. 408 U.S. 238 (1972). 
ting it revised" (p. 6) and proceeds with his analysis. ${ }^{43}$ But the proposition is demonstrably false, as a glance at either a cumulative "table of statutes affected" or the statistics on the volume of legislation - state or federal will quickly reveal. Most legislation adds to or amends existing legislation; very little tills totally new ground. ${ }^{44}$ That Calabresi devotes little attention to what legislative inertia is, and how it operates, is best illustrated by his discussion of the Supreme Court's struggle to keep the Federal Employer's Liability Act abreast of then current tort law by consistently interpreting it to allow plaintiffs to get to a jury with their claim:

One may well ask why Congress did not revise the laws and save the Court the trouble. But the reasons, grounded in the complex interplay of interest group politics, are of no special significance. Legislative inertia, absent Court action, was a fact of life in this area. [P. 34.]

Far from being "of no special significance," the "complex interplay of interest group politics" is the very stuff of legislative inertia; and there is little reason to suspect that, in most cases, it will be any less a fact of life when a statute is bounced back for reconsideration.

It simply is not plausible to argue that statutes, even very old statutes, are negative sum games, imposing useless costs that everyone would simply rather do without. They are, instead, most often zero sum games: one group's loss is measured by another's gain. They distribute benefits to some at the expense of others; those who bear the expense will not hesitate to shift their burden if they can make out an argument that they are now the relevant majority. And legislators know, as courts can never know, the peril of ignoring such arguments. Once passed, a particular statute often remains in force for precisely the same reason it was enacted originally: A small number of intensely interested individuals or groups will devote much time, effort and money to an issue because they have a much greater stake than the public at large in the statutory outcome. ${ }^{45}$

Indeed, Calabresi's own examples illustrate this best. The economist may know that rent control debilitates housing stock and narrows consumer choice, but it is obvious why those laws remain in force. And it is equally obvious that neither microeconomic nor macropolicy arguments ("a still predominantly 'free price' society" (p. 133)) are likely to dislodge such laws. The "emergency" legislation Calabresi is concerned with may be borne of crisis, but it creates its own constituency. ${ }^{46}$ And if the passage of legislation capping recoveries in products liability and medical malpractice suits indi-

43. P. 6 (citing G. GILMORE, supra note 8, at 95).

44. See, e.g., Rosenthal \& Forth, The Assembly Line: Law Production in the American States, 3 LEGIS. STUD. Q. 265, 269 (1978) ("Very few [statutes] create policies or programs from scratch; most amend existing law. Many add to already substantial regulations. Many are local legislation having only limited impact. Only a handful of all those introduced command widespread interest; not many more provoke intense controversy.").

45. See Pennock, Another Legislative Typology, 41 J. PoL. 1206, 1208-09 (1979) (analyzing statutes conferring particularized benefits and exacting generalized costs as unlikely to produce either intra-interest group conflict or taxpayer resistance).

46. The sixty-year-old American antidumping statute, 19 U.S.C. $\$ \$ 1202-1677$ (Supp. II 1979), is a classic example. In recent years the statute has been most frequently invoked by industries that have suffered from competitive imports, see Ehrenhaft, What the Antidumping and Countervailing Duty Provisions of the Trade Agreements Act (Can] (Will] (Should] Mean to U.S. Trade Policy, 11 LAW \& PoL. InTL. Bus. 1361, 1364, 1374 (1979) (brackets in original) 
cates anything, it is that defendants know an "end run" when they see it. 47 And what of the obsolescence of fair trade laws now, when the latest word is that resale price maintenance is no longer taboo? ${ }^{48}$ The only really good example of out-and-out legislative perversity that Calabresi adduces is the persistence, in several states, of limitations on wrongful death recoveries. But the example is dated, as he concedes, because "[t]his particular problem has been remedied by the legislatures" (p. 40). He is correct in pointing out that inflation has taken legislatures by surprise (p. 40), but it seems that courts have also had a little difficulty with the concept. ${ }^{49}$

But all this goes only to reinforcing the point made earlier regarding the "mismatch" between the vague majority-sentiment inquiry courts would conduct and the rather sharp jumble of majoritarian forces a statute would confront upon reconsideration. This mismatch augurs poorly for the predictive power of the doctrine, to be sure, but it does not militate against using the doctrine if one is confident that courts can, and should, redirect the legislative agenda. And if we assume that the topographic concept can be operationalized in a manner that will persuade legislators as well as the courts, it is possible that legislatures might make a concerted effort to reconsider those statutes brought to their attention by the courts.

This is an empirical question; different states will respond in their own way to such suggestions. Calabresi notes in passing the existence of law revision commissions, but fails to note that many states have committees or commissions charged with evaluating the statutory landscape for obsolescence. ${ }^{50}$ Some of these commissions and committees also monitor state court decisions, bringing suggestions and criticisms to the attention of the relevant legislative committee. ${ }^{51}$ His doctrine may add some urgency to such requests, but the staggering volume of legislation, at least at a state level, makes one less than sanguine that legislatures are likely to give a more reasoned consideration to an open-ended judicial request for reconsideration than they have in the past to the detailed suggestions from their

(most antidumping cases initiated by steel and chemical industries; cases are "pimples on the trade landscape").

47. In fact, there has been considerable pressure for a uniform federal law on products liability; opposition to date has come, as one might expect, from lawyers. See 51 U.S.L.W. 2474, 2475-76 (Feb. 15, 1983) (report of Mid-Year Meeting of the American Bar Association) (committee reaffirms ABA's opposition to proposed national products liability legislation).

48. See R. Bork, The Antitrust Paradox 288-91 (1978).

49. See, e.g., Comment, Inflation, Productivity, and the Total Offset Method of Calculating Damages for Lost Future Earnings, 49 U. CHI. L. REV. 1003 (1982); Note, Interest in Judgments Against the Federal Government: The Need for Full Compensation, 91 YALE L.J. 297 (1981).

50. See note 19 supra.

51. See, eg., AlASKa STAT. \$24.20.065(a)(1-3) (1979 Supp.) (requiring state legislative council to "annually examine administrative regulations, published opinions of state and federal courts and of the Department of Law that rely on state statutes . . . to determine whether or not ... the courts and agencies are properly implementing legislative purposes . . . [, or whether] there are court or agency expressions of dissatisfaction with state statutes . . . [, or whether] the opinions or regulations indicate unclear or ambiguous statutes."); $c f$. AlASKA Legislative AfFairs AgEnCY, RePort of EXAMINATION OF COURT Decisions ConstruING Alaska STATUTES RENDERED BY THE Supreme Court of AlasKa ii (1977) (introduction of report states that "Part Two consists of cases where the court specifically requests legislative guidance on an issue which is unsettled under existing law"). 
own staff as to how a law - even a fairly picayune law - should be modified.

Calabresi would skirt many of these difficulties, however, by suggesting how courts might best promote dialogue between themselves and the legislatures. The disadvantages of this, of course, are that if courts assume the more active role in this dialogue they risk displacing from the legislative agenda other issues that might have been considered and they invite a legislative response that will, in time, be no response at all. The first point may seem trifling unless one appreciates just how many statutes a typical legislature considers, and under what sort of constraints it operates. ${ }^{52}$ Adding a "sub-docket" of statutes that courts are troubled by may well leave less time for issues that legislatures have addressed because - is it possible? - the courts have not..$^{53}$ Shield laws, legal death statutes and school refinancing bills come to mind. The second point, however, is more bothersome. Again, a glance at the statistics on state legislation is helpful, if somewhat depressing. Whatever problem statutory obsolescence presents now, it is sure to grow worse in the future. The well-known tendency of Congress to pass the buck to the federal courts through vaguely worded statutes may make readers less than comfortable about accepting a doctrine that would let legislators comfort themselves with the notion that courts can also decide how an old statute should be modified. Then instead of courts telling litigants that they should argue their case to Congress, Congress can tell constituents that they should argue their statute to the courts.

\section{IV}

There can be no doubt that this book should be read by everyone concerned with the legal process. The scholarly interest that this book has already produced 54 suggests that it will be widely read, if not widely accepted. Debate about the role of judges will no doubt continue, and $\mathrm{Cal}$ abresi's novel theory is likely to become a point of reference. Whatever the ultimate merits of Calabresi's doctrine, his lucid and scholarly exposition is

52. In New York, for example, 21,682 bills were introduced in the 1979-1980 regular session; 734 of these bills were enacted into law. And of course there are resolutions - generally these are of little moment, but they do take up legislative time. Again, New York leads the pack with 1,503 resolutions introduced and 1,408 passed for the 1979 portion of the $1979-1980$ session. See Council of State Governments, 1981 Book of tHe States 206-7 (Table 13) (1982). The 50 state average for bills enacted in 1975-1976 was 853, Rosenthal \& Forth, There Ought to be A Lawl, 51 STATE GovT. 81 (1978). Although the number of bills introduced in state legislature has increased sharply in recent years, see Rosenthal \& Forth, supra note 44, at 272 , the number of bills enacted has not increased proportionately. This suggests that many legislatures might be functioning at or near institutional limits.

53. See, e.g., Kurfess, State Legislatures: A Record of Accomplishment, 47 STATE GovT. 247 (1974) (citing campaign finance reform (40 states), conflict of interest legislation (36 states) comprehensive land use planning (12 states), and public financing of education as areas where state legislatures had taken policy initiatives.); Legislating Death, 49 STATE GovT. 130, 134 (1976) ("Medical developments over the last several decades have created situations raising legal questions which are not adequately resolved by common law or existing statutes. In addressing the issues of criteria for the determination of death and guidelines for dealing with dying persons state legislatures will face many problems .... [T]he need to confront these issues . . . is inevitable.").

54. See note 3 supra. 
valuable for the light it casts into the misty area which separates legislative from judicial functions.

But Calabresi's doctrine is too big for the small problems, and too small for the big problems. The small problems - wrongful death limitations and archaic contributory negligence rules - do not justify revamping the legislative/judicial balance. For the big problems - those resulting from the inherent dynamic of majoritarian politics - provoking legislative reconsideration of senile statutes is unlikely to produce a more consistent body of positive law.

The failure, however, is not one of vision on Calabresi's part. He is "a man who wishes to make a profession of goodness in everything" and he therefore "must necessarily come to grief among so many who are not so good."55 Let the people complain to those who make the laws if the laws fail to pace the times. Meanwhile, courts ought to keep quiet about the subterfuges they use to do justice when someone is caught between a rock and a statutory hard place.

55. N. Machiavelli, The Prince ch. XV (Modern Library ed. 1968). 
The Politics of Judicial Reform. Edited by Philip L. Dubois. Lexington, Mass.: D.C. Heath \& Co. 1982. Pp. xi, 187. \$24.95.

Court reform involves much more than the modernization of outdated practices of judicial administration. By changing the organization and procedures of courts, court reform redistributes power within the court system and the larger community. The eleven essays in The Politics of Judicial Reform explore some of the ways that reform proposals create political conflicts among competing groups and interests and in turn shape the outcome of reform proposals.

Although earlier commentators have recognized the political significance of judicial reform, the literature on the subject is sparse. ${ }^{1}$ The Politics of Judicial Reform does not attempt to present a comprehensive survey, for as editor Philip $L$. Dubois notes, no single book could hope to treat comprehensively a topic as broad as the politics of judicial reform (p. 11). By highlighting some of the political ramifications of reform, however, Dubois illustrates the breadth of the subject and demonstrates the importance of its continued study.

The essays begin with an introduction to some of the basic political dimensions of court reform. Henry R. Glick emphasizes the role political parties play in court reform. Since state-level reforms generally "shift judicial administration from local control and independence to centralized court management" (p. 17), groups with vested interest in locally managed courts often oppose the reforms. According to Glick, these groups include local judges and court employees; the Democratic Party, which has a strong influence on judicial elections in its urban strongholds; and general-practice and trial lawyers, who are accustomed to existing structures and who are usually Democrats (pp. 23-25). The proponents of reform often include bar associations, ${ }^{2}$ the federal government, middle class civic organizations, the Republican Party, ${ }^{3}$ and "high-status" lawyers, who are often bar activists and Republican partisans (pp. 20-23). Although proponents have achieved recent successes in streamlining and consolidating the courts, Glick observes that state court systems remain highly decentralized. ${ }^{4}$

Glick probably overstates the partisan aspect of court reform. First, Republican advocacy of court reform may be limited to cities, where the party lacks power. As Glick notes, legislative opponents of court reform "come

1. Geoff Gallas has observed the political aspect of court reform and suggested that it needs to be explored. See Gallas, Court Reform: Has it been Built on an Adequate Foundation?, 63 JUDICATURE 28, 37 (1979). For other works on the political aspects of judicial reform, see notes 13 \& 14 infra.

2. Glick suggests that bar associations became involved in court reform to improve the image and economic status of lawyers and the image of justice in general. One of their prime concerns has been the elimination of partisan influence in the selection of judges in favor of merit-based selection. P. 20.

3. Glick notes that Republican officials frequently oppose the link between judges and local party politics in order to lessen Democratic influence in urban politics. P. 24-25.

4. For example, Glick notes that state courts remain largely dependent upon local government for funding. P. 27. 
more often from rural areas where traditional values and local control are more important" (p. 25). In states with large urban populations, the rural or outstate legislators have come predominantly from the Republican Party. ${ }^{5}$ Second, Glick presents no solid evidence linking general-practice and trial lawyers with the Democratic Party. He notes only that these lawyers occupy lower rungs on the socioeconomic ladder than do "high-status" lawyers (p. 24). If socioeconomic status is taken as a measure of partisanship, general-practice and trial lawyers may be less likely to be Republicans than their "high-status" counterparts. Given the relatively high socioeconomic status of lawyers as a group, however, lower status lawyers do not necessarily share a strong Democratic predisposition.

The essays in Part II examine court reform in a broader political context. Frank Munger argues that popular political upheavals have influenced the major court reform movements of this century (pp. 51-67). Court reform, according to Munger, has been led historically by legal elites which "carry out a self-appointed mandate to improve the court system" (p. 53). Although these elites have sought to protect their own interests, they also have attempted to restore legitimacy to threatened governmental institutions by strengthening the credibility of the legal system (pp. 61-62). ${ }^{6}$ During the Progressive Era, court reformers strove to assist those classes with little political influence by attacking cumbersome procedures and poor administration of local courts (pp. 55-56). During the New Deal, realist legal theory helped reformers rationalize the transfer of policy enforcement from the courts to administrative tribunals as ensuring greater popular control over government decisionmaking (pp. 57-59). Since the 1960's, court reformers have attempted to divert relatively unimportant cases from the courts to accommodate the increasing number of cases involving important political issues that other branches have not handled (pp. 59-61). Thus, although court reform is commonly justified in terms of efficiency, the ideals of court reform have changed when differing demands have been placed on the government and the courts (p. 62). ${ }^{7}$

Against this backdrop, Richard Gambitta and Marlynn May suggest that reforms designed to increase access to the courts and reduce court congestion have combined to create popular dissatisfaction with the courts (pp. 69-83). Under these reforms, more people have contact with the judicial system, but their disputes are often settled through informal negotiation and reconciliation rather than formal adjudication. Gambitta and May ar-

5. See T. Dye, Politics in STates and Communities 104 (2d ed. 1973); V. KeY, AmerIcan State Politics 230-34 (1956).

6. Munger's analysis modifes the views of Lawrence Friedman, who sees judicial reform solely as a self-serving activity undertaken by elites in the legal profession to maintain their control within the profession and create a favorable public image. See Friedman, Law Reform in Historical Perspective, 13 ST. LouIs U. L.J. 351, 357-58 (1969). Munger argues that Friedman "does not devote sufficient attention to the continuous pressures on lawyers to maintain compatibility between the legal system and other institutions in the society." P. 54.

7. During the Progressive era, efficiency, Munger suggests, meant greater access to governmental institutions. In the New Deal-Realist period, it meant doing away with normative distinctions between judiciary and administration and accepting the bare fact of authority or power. Recently, it has had a strong overtone of excluding unimportant, minor, and new rights. P. 62. 
gue that courts derive legitimacy from popular acceptance of "the myth of the triad" (p. 73). The elements of the triadic model are (1) a neutral judge who resolves disputes by (2) applying preexisting rules to cases presented in adversarial proceedings and (3) publicly explaining the reasons for the decision. ${ }^{8}$ Reforms, Gambitta and May conclude, are eroding the triad's acceptance and contributing to reported increases ${ }^{9}$ in popular dissatisfaction (p. 79).

Gambitta and May, however, lack the necessary empirical evidence to support their position. ${ }^{10}$ Without such evidence, one could assert with equal plausibility that informal methods of resolving disputes actually limit popular disillusionment with the courts. Formal proceedings are often costly and time-consuming. In spite of reforms aimed at reducing congestion, they also may be marked by long delays. Informal methods allow parties to avoid these obstacles. Moreover, parties may be more satisfied with a result to which they have agreed than with a court-imposed result. Further empirical study seems necessary to determine the popular impact of informal dispute resolution.

Following a collection of legislative and administrative case studies in Parts III and IV, Larry Cohen attacks current "depoliticized" methods of evaluating the competency of judges. These methods, Cohen argues, preclude public input, because they attempt to measure qualities, such as "legal ability" and "judicial temperament," that are "either unobserved by those outside the legal process or simply inaccessible to the objective assessment" (p. 170). Cohen asserts that "repoliticizing" the competence issue would give the public a genuine role in evaluating the courts. Somewhat vaguely, Cohen advocates repoliticization through surveying "lawyers, other court actors, clients, interest-group representatives, and the various sectors of the general public" (p. 173). Cohen concedes that a repoliticizing process will be difficult to develop and operationalize, but he contends that methods can be developed from current social science models (pp. 172-73).

Although consonant with current trends in the critical legal studies movement, Cohen's proposal cuts against the grain of modern court reform. To promote professionalism in the judiciary, reformers have sought the depoliticization (or "professionalization") that Cohen assails, largely through efforts to abolish judicial elections. ${ }^{11}$ Curiously, Cohen does not advocate elections as a possible means of repoliticization, ${ }^{12}$ and he fails to explain

8. The triadic model as an ideal legitimating the courts has been proposed by many scholars. See, e.g., T. ARNold, The SYMBols OF GovernMent (2d ed. 1962); Amold, Law En-

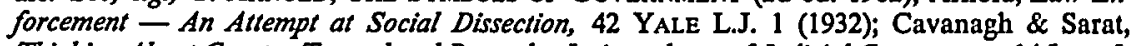
Thinking About Courts: Toward and Beyond a Jurisprudence of Judicial Competence, 14 LAW \& SOCY. REv. 371 (1980); Fuller, The Forms and Limits of Adjudication, 92 HARv. L. REv. 353 (1978); Sarat, Support for the Legal System: An Analysis of Knowledge, Attitudes and Behavior, 3 AM. POL. Q. 1 (1975).

9. See Yankelovich, Skelly \& White, Inc., The Public Image of Courts (1978).

10. Gambitta and May admit that an empirical study is necessary to validate their argument. P. 80 .

11. Glick notes these efforts in his essay. Pp. 19-20.

12. Cohen's admitted aim is to "invigorate the political element in competence discussions while retaining the admitted expertise of those particularly well suited to observe judicial behavior. . . P. P. 171-72. 
why elections do not give the public sufficient input in those jurisdictions that retain them. Yet even though he avoids this sensitive issue, leaders of the bar are likely to view his proposal skeptically, as too great an intrusion on judicial professionalism.

The Politics of Judicial Reform sketches a broad outline of its subject, focusing on some of its aspects and leaving others unexplored. The essays, while provocative, are at times speculative and lacking in depth. Dubois suggests that interested readers should supplement this book with the few other collections ${ }^{13}$ and case studies ${ }^{14}$ in the area (p. 11). Still, The Politics of Judicial Reform offers a unique introduction to "aspects of judicial reform [that] have been too long neglected by court-reform leaders and students of the courts" (p. 2).

13. E.g., L. Berkson, W. Hays \& S. Carbon, Managing The State Courts (1977); R. WhEELER \& H. WHITCOMB, JUdicial ADMINISTRATION (1977). While somewhat more detailed than Dubois's collection, these works do not share its strong emphasis on the political factors underlying judicial reform.

Dubois has edited another collection designed to complement this one. See P. DuBors, THE ANALYSIS OF JUdiCIAL REFORM (1982).

14. E.g., L. Berkson \& S. Carbon, Court Unification: History, Politics and IMplementation (1978); P. Fish, The Politics of Federal Judicial Administration (1973). Berkson and Hays focus upon state court reform, presenting some detail on campaigns to achieve court reform. Fish's work, as the title suggests, deals solely with federal reforms, offering an historical survey beginning in the early days of the republic. 

David J. Saari. Westport, Conn.: Quorum Books. 1982. Pp. xviii, 163. $\$ 27.50$.

Despite the relative abundance of unhappy commentary on the inability of our judicial system to process its caseload efficiently, there is a dearth of literature on the use of management theory and techniques to ease the burden of courtroom administration. In American Court Management, David $\mathrm{J}$. Saari ${ }^{1}$ makes a valuable contribution to this relatively new field; one to which judges and court administrators will probably refer in the course of managing litigation. Saari, himself a former court administrator, notes at the outset that both legal scholars and political scientists have made some significant contributions to the field of court management. ${ }^{2}$ These approaches, however, have failed to recognize judicial management as an independent discipline, or, as Saari puts it, as "an emerging and evolving multidisciplinary profession" (p. 4). Of course, in new professions one finds new groups of professionals. Saari directs his analysis primarily to the role of these professionals - contemporary court administrators.

While Saari claims to analyze court management from a multidisciplinary perspective, his book does not range far from the principles of business administration (which might itself be considered multidisciplinary). In the first part of the book, the author reviews four schools of management theory: the "bureaucratic," "human relations," "systems," and "contingency" perspectives. ${ }^{3}$ This discussion is somewhat cursory; the relation between the theories and practical role of the court manager is left unclear. The author suggests only that court administrators "keep an open mind" as to the theories propounded and "be open to further education as the field changes ...." (pp. 25-26).

One of the more disheartening aspects of this discussion is Saari's dis-

1. Professor, School of Justice, American University. Professor Saari served as a trial court administrator for eighteen years prior to joining American University.

2. Saari observes that addressing the problem from a legal perspective "stresses the judicial role, the formalities of trial, the intricate questions of jurisdiction and power of court, and the jury-trial practice." P. 3. See, e.g., D. Nelson, Judicial AdMinistration AND THE ADMINISTRATION OF JUSTICE (1974). Likewise, Saari finds the political science perspective to be dominated by questions of power and general public welfare. P. 4. See, e.g., E. FRIESEN, JR., E. Gallas \& N. Gallas, Managing the Courts (1971).

3. Saari cites Max Weber as his source for the "bureaucratic perspective." Pp. 20-21. See M. Weber, The Protestant Ethic and the Spirit of Capitalism (1958); From Max WEBER: ESSAYS IN Sociology 196-244 (H. Gerth \& C. Mills eds. 1946). The "systems perspective" is part of the progeny of classical bureaucracy. While retaining notions of bureaucratic structure, this perspective sees itself as an "open system," continuously interacting with the environment. Pp. 23-24. See generally H. KoonTz, C. O'DonNell \& H. WeIRICH, MANAGEMENT 24-28 (7th ed. 1980). The "human relations" approach involves fostering the needs of workers and managers so as to create an environment that will enhance efficiency. Pp. 2223. The contingency approach is described as advocating that there is "no best way" to manage and that an organization must have the flexibility to adjust and adapt to changes in the environment. Pp. 24-26. Saari seems to favor this perspective. See J. Thompson, OroANizaTIONS IN ACTION: Social. Science Bases of ADMINISTRATIVe Theory (1967). 
dain for the "bureaucratic perspective." He claims that "sick bureaucrats may be so fearful that they overpaper the world . . . to account for their behavior ....." and that "[b]ureaucratic approaches to management are coercive and authoritarian" (p. 21). Judicial administrators, however, will face a great deal of difficulty in designing an efficient docket-management system that is not "bureaucratic." To the extent Saari's indictment condemns "bureaucratic" mindsets rather than institutional structures, few will find his argument either unpersuasive or informative. A computerized, assembly-line judicial system administered by humane and flexible individuals is immune to this critique; a disorganized, decentralized administrative structure governed by unimaginative martinets is guilty of all with which Saari charges bureaucracy, although some other label might better describe such a system. Also distressing is Saari's failure to address meaningfully the opportunity to accommodate the positive aspects of the four schools of managerial thought in a single theoretical model, a position advocated by several noted theorists. ${ }^{4}$

In the second part of the book, Professor Saari discusses the emergence of court management theory in several basic areas including structure, effectiveness, and decisionmaking. The fundamental message which emerges from this analysis is that there is no "best way" to manage a court; "America's courts are home-grown products of very local cultures" (p. 32), and what is best for the courts of Chippewa Falls, Wisconsin 5 may not be best for those of Seattle, Washington. This view might suggest, as Saari intimates, opting for the "contingency perspective" which would permit a continuous adjustment of structure and goals in court management as communities grow and change. In his discussion relating to organizational effectiveness, however, the author deals primarily with the attainment of goals and periodic self-assessment by court managers: an analysis which is highly reminiscent of the bureaucratic perspective.

Perhaps Saari's most interesting and useful application of court management theory concerns decisionmaking. In Saari's view, judges wear three hats: adjudicative, administrative, and political. While their main service is adjudication, the majority of the nonfederal bench is elected and must periodically devote time and energy to the electoral process. Additionally, judges, like many other professionals (Saari notes lawyers, physicians, and university professors in particular) have a secondary role which is administrative. The author notes that judges often regard this latter role as "an unwanted administrative chore" which, in the context of a multijudge bench, is rotated frequently (p. 50). This is also reflected in a survey of judges discussed in regard to judicial morale later in the book. ${ }^{6}$ The constraints which time and lack of motivation place on the functioning of judges in their role as administrators make it unlikely that judges will oper-

4. See, e.g., R. Hall, Organizations: Structure and Process 49-66 (1977); H. KOONTZ, C. O'DONNELL \& H. WeIHRICH, supra note 3, at 73-78.

5. See F. Laurent, The Business of a Trial Court, 100 Years of Cases: a Census of the Actions and Special Proceedings in the Circuit Court for Chippewa falls, WISCONSIN, 1855-1954 (1959).

6. Saari cites a survey of judges which indicates that the factor tending to detract the most from judicial morale was "too much pressure to move cases." P. 123. See J. RYAN, AMERICAN TRIAL JUDGES 240-42 (1980). 
ate effectively in that role. As a result, Saari emphasizes that defective court management "will probably impinge upon the adjudicative role of the judges and thereby contribute to production of substandard justice . . ." (p. 53). The court administrator, then, must assume generally this administrative role while steering clear of the adjudicatory and political roles. In subsequent parts of the book, however, the author makes clear that this, to a significant degree, is easier said than done.

In the third part of American Court Management, Saari looks at the responsibilities of the court administrator in managing the quotidian details of a functioning judicial system - case-flow, personnel, finances, records, etc. The author describes case-flow as one of the most difficult managerial tasks confronted by court administrators, and certainly one of the most important. Saari finds it particularly difficult to manage case-flow because, as he sees it, cases are "fights" and "[i]n fighting, one does not feel obligated to agree upon the "time of day," so to speak. Therefore, fight scheduling is easy in boxing, but very difficult in the courtroom" (pp. 69-70). While case-flow management is no easy task, the difficulty probably does not result solely from the parties' interest in delay. At least in part, case-flow management is tricky business because of the number of unknown quantities, i.e., settlement possibilities, joinder of claims and parties, cases remanded, and other variables which make reasoned predictions difficult. In any event, Saari helpfully draws together several factors which contribute to a more predictable case-flow. These include (1) continuous cognizance and control of the progress of individual cases, (2) the establishment of a simple record system specifically designed to facilitate case-flow, (3) the use of case processing time standards and case-flow performance standards to monitor delay and to provide feedback in the case-flow process. In these suggestions, and in the author's emphasis on control, however, the haunting presence of classical bureaucracy makes itself felt once again. It seems that if goals of judicial efficiency are to be set, monitored, readjusted, and ultimately achieved, the courts must depend on at least some degree of bureaucratic structure.

Apart from administrative tasks involving personnel management, the preparation of financial studies and budget requests, and the supervision of an ever-growing records system, Saari, in the last part of American Court Management, discusses important policy questions in which court managers are likely to become involved. The first of these relates to the problems of case-flow management and deals with the duty of the court administrator to schedule criminal trials in compliance with the "speedy trial" mandate of the sixth amendment. The author suggests that state court administrators must make a policy decision as to whether to adopt individual versions of the federal Speedy Trial Act, which sets time standards for the disposition of all pretrial matters. While this is a policy decision in which the court administrator will play a key role, Saari warns that "[u]ncritical acceptance of speed at any cost is unacceptable policy development" (p. 104).

A second policy problem which Saari sees court administrators facing in the future is the inability to secure adequate and "equal" counsel for indigent criminal defendants. He notes that the present mood of fiscal restraint threatens the court manager's ability to secure an adequate number of com- 
petent defense counselors. What the administrator can practically accomplish under this scenario is not altogether clear, but Saari suggests that

[c]ourt managers will probably need to probe much more deeply into the way professional service of defense is offered to assess quality, cost, and availability within speedy-trial standards and to prepare assessments for public consumption on the integrity and cost-effectiveness of the public defense function. (pp. 108-09).

Unfortunately, given political constraints on judicial resources, the most thorough and creative studies are unlikely to result in more competent counsel or speedier trials for all criminal defendants. In an era of expanding dockets and shrinking resources, either or both of these judicial components must suffer. The only way in which a court administrator might act to stem this tide is through the development of more efficient information access and,processing devices.

Another policy issue which the author sees the court administrator ultimately confronting is the institution and management of equal opportunity and affirmative action personnel politics. Here, Robert Tobin is quoted as saying that "most trial courts do not embrace activist concepts of equal opportunity employment . . ."7 (p. 110). The public reaction to an awareness that the judiciary does not abide by the equal or affirmative hiring criteria it imposes on the private sector would dramatically diminish the perceived legitimacy of court-enforced compliance with those important standards. Saari suggests that court managers are in an excellent position to institute studies and programs "to improve the egalitarian, representative nature of court employees" (p. 111).

At present the field of court management is limited to case-flow, personnel, financial, and records management. In a prognosis of the field, Saari sees a greatly expanded role for the court administrator, one which involves participation in the decisionmaking process concerning important policy questions, serving as the court's liaison to other agencies and branches of government as well as to the public, and acting generally to improve judicial morale. American Court Management makes an important contribution toward achieving these goals by confirming the status of court administration as a professional field of study and practice, grounded firmly in theories of organizational management, yet unique in its partnership with the American system of justice.

7. R. Tobin, Trial Court Management Series: Personnel Management 40 (1979). 